\title{
Thermobarometry of the Moine and Sgurr Beag thrust sheets, northern Scotland
}

Sarah E. Mazza1*, Calvin Mako1, Richard D. Law1, Mark J. Caddick1, Maarten Krabbendam2, John Cottle3

1Department of Geosciences, Virginia Tech, 4044 Derring Hall (0420), Blacksburg, VA 24061

2 British Geological Survey, Murchison House, Edinburgh EH6 3LA, United Kingdom

3Department of Earth Science, University of California, Santa Barbara, CA 93106

\#Now at Institut für Planetologie, Westfälische Wilhelms-Universität Münster, 48149 Münster,

Germany

*Corresponding author mazza@uni-muenster.de

\begin{abstract}
In the Caledonides of northern Scotland temperatures of metamorphism (Tm) and deformation (Td) progressively increase structurally up section in the Moine thrust sheet at the foreland edge of the Scandian (mid Silurian) orogenic wedge. However, the thermal history of the structurally overlying, more hinterland positioned thrust sheets is less well known. This study focuses on determining Td and Tm for both the central/upper part of the Moine thrust sheet and the lower part of the overlying Sgurr Beag thrust sheets in the middle of the Northern Highlands Terrane.

Preserved microstructures and quartz $\mathrm{c}$-axis fabric opening angles in the Moine and Sgurr Beag thrust sheets imply $\mathrm{Td}$ of $460^{\circ} \mathrm{C}$ to $605^{\circ} \mathrm{C} \pm 50{ }^{\circ} \mathrm{C}$. Thermobarometry and pseudosection-based P-T constraints, indicate $\mathrm{Tm}$ of $\sim 550-680^{\circ} \mathrm{C}$ at $4.8-7.2 \mathrm{kbar}$ in the Moine thrust sheet and $\mathrm{Tm}$ of $\sim 620^{\circ} \mathrm{C}$ at 5.6-7.7 kbar in the Sgurr Beag thrust sheet. Together, Td and Tm in the Moine and Sgurr Beag thrust sheets indicate that deformation continued after peak metamorphic conditions in the Sgurr Beag thrust sheet. Monazite and xenotime petrochronology show that Tm, and possibly Td, record Precambrian metamorphism. Peak metamorphism is associated with the Knoydartian orogenic event (840-720 Ma), with possible reworking during Scandian thrusting (430-425 Ma).
\end{abstract}

Keywords: Northern Scotland Quartz fabrics Deformation temperatures Monazite and xenotime petrochronology Thermobarometry 


\section{Introduction}

Within the Caledonian age eastward-dipping Moine and structurally overlying thrust sheets (or nappes) in the Northern Highlands Terrane of Scotland (Fig. 1) deformation fabrics in quartz-rich psammites and metamorphic indicator minerals in rare intercalated pelite horizons suggest that temperatures of deformation $(\mathrm{Td})$ and metamorphism $(\mathrm{Tm})$ progressively increase structurally up section from foreland to hinterland (Soper and Brown, 1971; Winchester, 1974; Barr et al., 1986; Johnson and Strachan, 2006; Thigpen et al., 2010, 2013). Historically, this foreland-to-hinterland temperature increase has been interpreted as being due to either west-directed thrusting of hotter rocks over cooler rocks or late-stage penetrative low-temperature retrograde shearing and overprinting of originally higher temperature rocks during foreland-propagating thrusting (Peach et al., 1907; Read, 1931; Butler, 2010). In the Northern Highlands, pressure and temperature (P-T) data are limited (Soper and Brown, 1971; Barr et al., 1986; Burns, 1994; Friend et al., 2000; Zeh and Millar, 2001; Cutts et al., 2009, 2010; Ashley et al., 2015) due to the dominance of quartzofeldspathic units in the Moine Supergroup metasedimentary rocks and the relative scarcity of pelite horizons containing assemblages of metamorphic indicator minerals suitable for thermobarometry.

Using quartz c-axis fabric opening angles and garnet-biotite thermometry, Thigpen et al. (2013) quantified a foreland-to-hinterland increase in Tm and Td across the Moine, Ben Hope, and Naver thrust sheets of northern Scotland, in an area extending from the north coast southwards towards the Assynt district (Fig. 1). Based on their data and thermal-kinematic modeling, Thigpen et al. (2013) interpreted the foreland-to-hinterland increase in $\mathrm{Tm}$ and $\mathrm{Td}$ in the Moine and structurally higher thrust sheets as being associated with a right-way up (non-inverted) thermal structure, developed at the orogenic wedge scale, in which isotherms dip steeply towards the foreland.

In order to further understand the thermal and temporal structure associated with penetrative shearing within the Moine and Sgurr Beag thrust sheets, we present estimates of temperatures of deformation and metamorphism, together with pressure and timing constraints obtained within four sampling areas along a transect from Ullapool along Loch Glascarnoch to the Creich Peninsula, and located to the south of the area described by Thigpen et al. (2013). Deformation temperatures for quartz-rich units are estimated using the quartz c-axis fabric opening angle thermometer (Kruhl, 1998) and are compared with qualitative temperature ranges indicated by quartz recrystallization regimes associated with fabric development (Stipp et al., 2002). Metamorphic temperature, pressure, and timing constraints for metamorphism of pelitic units from the Sgurr Beag thrust sheet are estimated using compositional thermobarometry, pseudosection modeling, and monazite and xenotime geochronology. Pseudosection data are also included from the Loch Glascarnoch location in the central/upper part of the Moine thrust sheet. Sample locations and the various types of analyses carried out on individual samples are summarized in Table 1.

\section{Geological background}

In the study area located between Ullapool, Fannich Forest, Ben Wyvis/Garve, and the Creich Peninsula (Fig. 1) the Northern Highlands Terrane is dominated by two major regional thrust sheets: the structurally lower Moine thrust sheet exposed in the west and the structurally higher Sgurr Beag thrust sheet in the east. Below the Moine thrust sheet is the predominantly brittle Moine Thrust Zone, which marks the foreland edge of the Caledonian orogenic wedge, and was first systematically described by Peach et al. (1907). The Moine Thrust Zone deforms a Cambro-Ordovician shelf sequence (Peach et al., 1907), Neoproterozoic age Torridon Group sandstone (Stewart, 2002), as well as Archaean-Paleoproterozoic Lewisian gneiss (Park, 2005). The Moine thrust zone is a gently eastward dipping series of thrust faults that broadly separates unmetamorphosed units in the 
footwall from metamorphic rocks in its hanging wall. The hanging wall Moine Supergroup consists of a sequence of Neoproterozoic metasedimentary rocks that are locally cut by pre-, syn-, and posttectonic igneous bodies (Strachan et al., 2002).

The Moine Supergroup is subdivided from oldest to youngest into the Morar, Glenfinnan, and Loch Eil Groups (see reviews by Holdsworth et al., 1994; Strachan et al., 2002, Strachan et al., 2010a). The Morar Group is structurally located between the Moine Thrust and the overlying Sgurr Beag thrust (SBT), and comprises a $>8 \mathrm{~km}$ thick sequence of mainly psammite and minor pelite, that has been correlated with the Torridon Group exposed in the foreland to the west (e.g. Krabbendam et al., 2008, 2017; Bonsor et al., 2010). In the study area, the Morar Group occurs in a single nappe (i.e. the Moine thrust sheet), without intervening thrusts, but is thickened by west-vergent folds that may detach on the underlying Moine thrust (Krabbendam et al., 2011). In contrast, further to the north in Sutherland, the Morar Group is thickened by additional thrusts such as the Ben Hope and Achness thrusts, commonly with thin slices of Lewisian basement gneiss at the base of the overlying thrust sheet (Fig. 1, e.g. Holdsworth, 1989, 1990; Thigpen et al., 2013).

The SBT is an east-southeast dipping structure that emplaced Lewisian gneiss basement slices and Glenfinnan and Loch Eil group metasediments over Morar Group rocks (e.g. Tanner, 1970; Rathbone and Harris, 1979; Barr et al., 1986). The Glenfinnan Group is dominated by semipelitic and pelitic rocks, whereas the stratigraphically higher Loch Eil group comprises mainly psammite (Holdsworth et al., 1994; Strachan et al., 2010a; b). In the far north, in Sutherland and Caithness, the Naver, Swordly, and Skinsdale thrusts all deform high-grade metamorphic rocks, making correlation with units to the south uncertain.

At least four major orogenic events have affected the Moine Supergroup in northern Scotland: 1) the Knoydartian orogeny, probably in two phases between 840 and 720 Ma (Giletti et al., 1961; Vance et al., 1998; Rogers et al., 1998; Tanner and Evans, 2003; Cutts et al., 2010; Cawood et al., 2015), 2) the Grampian orogeny from 470 to $460 \mathrm{Ma}$ based on U-Pb zircon ages and garnet geochronology (Kinny et al., 1999; Rogers et al., 2001; Bird et al., 2013) and, 3) the Scandian orogeny at 430-425 Ma Ma based on a wide range of syn- and post-thrusting igneous intrusions (e.g. Kinny et al., 2003a; Kocks et al., 2006; Strachan and Evans, 2008; Goodenough et al., 2011). A suite of granites intruded the Moine Supergroup at 600-585 Ma, likely associated with rifting of the lapetus Ocean farther south (Kinny et al., 2003a; Oliver et al., 2008). In the upper part of the Moine thrust sheet immediately to the north of the study area, regional kyanite grade metamorphism appears to post-date intrusion of the 594 Ma Carn Chuinneag granite (Fig. 1; Peach et al., 1912; Tilley, 1935; Harker, 1954; Shepherd, 1973; Oliver et al., 2008 their Table 1). An episode of deformation and garnet grade metamorphism may also pre-date the Carn Chuinneag intrusion (see discussion in Kelley, 1984). Recent data also suggest a poorly understood late Ordovician phase of metamorphism at 455-445 Ma (Bird et al., 2013; Cawood et al., 2015). These orogenic events affect the various lithotectonic units differently, with the entire Moine Supergroup being deformed during the Scandian event (Kinny et al., 2003a). The age of final Scandian age thrusting/shearing (assuming a foreland propagating sequence) is bracketed between 431 and $429 \mathrm{Ma}$, based on U-Pb zircon dating from syntectonic igneous intrusions within the Moine Thrust Zone in Assynt (Goodenough et al., 2011, Fig. 1).

Traced from foreland to hinterland (Fig. 1), rocks of the Moine, Ben Hope, and Achness thrust sheets have been subjected to greenschist - lower amphibolite-facies metamorphism, while rocks of the overlying Naver, Swordly, and Skinsdale thrust sheets are associated with higher grade metamorphism, commonly showing migmatitic textures (Barr et al., 1986; Moorhouse and Moorhouse, 1988; Kocks et al., 2006). The SBT exposed in the study area was originally thought to connect northwards with the Naver thrust (Strachan and Holdsworth, 1988). However, recent 
studies noting differences between migmatites in the Naver and Sgurr Beag thrust sheets have suggested that the SBT may connect with the Skinsdale thrust (Kocks et al., 2006; Mendum et al., 2009). Syntectonic igneous intrusions associated with the Naver and Skinsdale thrusts indicate a Scandian age (Kinny et al., 2003a; Kocks et al., 2006). In contrast, Tanner and Evans (2003) regarded metamorphism associated with motion along the SBT further south as Knoydartian (c. $750 \mathrm{Ma}$ ) in age. The Glenfinnan group, and the Morar Group in Knoydart, is locally cut by pegmatites of Knoydartian age prior to subsequent folding and shearing (Long and Lambert, 1963; Wilson, 1975; Rogers et al., 1998; Hyslop, 1999; Cawood et al., 2015). K-Ar muscovite cooling ages suggest that motion on the SBT in the Fannich Forest area (Fig. 1) is older than $443 \pm 9 \mathrm{Ma}$, while early movement on the underlying Moine thrust occurred at 440-435 Ma with the thrust zone still active at $\sim 421 \pm 2.5$ Ma (Kelley, 1988, p. 8-9). The age(s) of motion on the SBT remains uncertain.

Rocks of the Moine thrust zone were deformed under greenschist-facies conditions, with deformation temperatures ranging between $\sim 300$ and $400{ }^{\circ} \mathrm{C}$ (see reviews by Strachan et al., 2002; Butler, 2010; Law and Johnson, 2010). Metamorphism associated with thrusting in the Scandian orogenic wedge increases from upper greenschist in the foreland (Moine thrust zone) to mid-and upper-amphibolite facies in the hinterland (Soper and Brown, 1971; Powell and Phillips, 1985; Holdsworth, 1989; Ashley et al., 2015). Morar Group metasedimentary rocks (Fig. 1) reached peak temperatures in the mid-to lower amphibolite facies (Fettes et al., 1985; Thigpen et al., 2010), while Glenfinnan Group rocks in the overlying Naver thrust sheet reached upper amphibolite facies (Soper and Brown, 1971). Quantitative constraints on P-T conditions are limited, with temperatures and pressures of $640-660^{\circ} \mathrm{C}$ and $5 \mathrm{kbar}$ estimated from garnet-biotite thermobarometry for the Naver thrust sheet (Burns, 1994; Friend et al., 2000) in the northernmost part of the Northern Highlands terrane (Fig. 1). Above the Ben Hope thrust to the west (located within the upper part of the Moine nappe sensu latto; Fig. 1), P-T conditions are estimated at $475^{\circ} \mathrm{C}$ at $3-4 \mathrm{kbar}$ (Burns, 1994). Due to a lack of suitable mineral assemblages, there are no P-T constraints for the Skinsdale thrust sheet (Kocks et al., 2006).

\section{Analytical methods}

\subsection{Microstructures and quartz c-axis fabrics}

Thin sections for microstructural and fabric analyses were cut parallel to lineation and perpendicular to foliation, and examined using an optical petrographic microscope mounted with a Leitz universal stage. Quartz c-axis fabrics were measured optically on recrystallized grains; a minimum of 500 grains (and maximum - and mode - of 1000 grains) were measured in each sample. Data were processed using an Excel macro developed by S. Mulcahy at University of California, Davis. Fabrics were plotted and contoured on a lower hemisphere stereonet using the Stereoplot software package developed by N. Mancktelow at ETH, Zurich.

Microstructural and quartz fabric analyses are reported here for samples collected in the Moine and Sgurr Beag thrust sheets exposed from west to east in the following areas: 1) Meall an T-Sithe (MAT), 2) Loch Glascarnoch, 3) Ben Wyvis/Garve and, 4) Creich Peninsula (Fig. 1, Fig. 2). The quartz c-axis fabrics reported here have been selected from a large suite of 50 fabric measurements collected across the Moine and Sgurr Beag sheets and also extending along the cross-section line shown in Fig. 2 (Law et al., 2017 and in prep). In this paper we have only included fabrics immediately adjacent to locations in the four study areas where we also report pressure-temperature estimates derived from metamorphic mineral assemblages. 


\subsection{Deformation temperatures from quartz recrystallization microstructures}

Quartz microstructures associated with dynamic recrystallization are classified using the terminology proposed by Stipp et al. (2002). The three main recrystallization mechanisms in quartz (grain boundary bulging, subgrain rotation and grain boundary migration) can be used to infer broad ranges of likely deformation temperature, assuming 'average' geologic strain rates (Stipp et al., 2002; Law, 2014). Grain boundary bulging (BLG) textures, with small ( $10 \mathrm{~mm}$ ) recrystallized quartz grains located adjacent to parent grain boundaries, are regarded as indicating deformation temperatures of $280-400{ }^{\circ} \mathrm{C}$. At $400-500^{\circ} \mathrm{C}$, subgrain rotation (SGR) is regarded as the dominant recrystallization mechanism, and is indicated by an increase in recrystallized grain size $(15-30 \mu \mathrm{m})$, a higher percentage of recrystallized grains and a "core and mantle" type microstructure. Above 500 ${ }^{\circ} \mathrm{C}$, grain boundary migration (GBM) becomes dominant. GBM is indicated by large recrystallized grains $(>30 \mu \mathrm{m})$ with lobate grain boundaries. Care needs to be taken in interpretation of recrystallization microstructures if second phases are present, as grain boundary pinning may occur and grain growth can be inhibited (Olgaard and Evans, 1986; Krabbendam et al., 2003).

\subsection{Deformation temperatures from quartz c-axis fabric opening angles}

Deformation temperatures associated with penetrative shearing in the studied samples were estimated using the quartz c-axis fabric opening angle thermometer described by Kruhl (1998), based on compiled results from multiple field-based studies correlating fabric opening angles with temperatures of deformation and/or metamorphism. The approximate inferred relationship between opening angle and deformation temperature is linear through greenschist to mid-upper amphibolite-facies conditions (Kruhl, 1998; see discussion by Morgan and Law, 2004; Faleiros et al., 2016) and is limited to deformation temperatures below $\sim 650-700{ }^{\circ} \mathrm{C}$. Temperature estimates based on the Kruhl (1998) opening angle thermometer are usually quoted with a nominal uncertainty of $\pm 50^{\circ} \mathrm{C}$ and are dependent on critical resolved shear stresses for operative crystal glide systems being primarily controlled by deformation temperature, rather than hydrolytic weakening or strain rate (Tullis et al., 1973; Lister and Hobbs, 1980; Law et al., 2004; Morgan and Law, 2004; Law, 2014).

\subsection{Metamorphic pressure-temperature estimates}

Samples from three localities within the Sgurr Beag thrust sheet and one locality within the Moine thrust sheet contained biotite + garnet + plagioclase + muscovite assemblages, making them suitable for quantitative thermobarometry. These locations include from west to east (Fig. 1; Table 1): a) the MAT/Sgurr Beag klippe (sample SB-12-10B); b) the Moine thrust sheet exposed along Loch Glascarnoch (MT-12-10) and the Sgurr Beag thrust sheet exposed in c) the Ben Wyvis/Garve area (SB-12-03A) and d) the Creich Peninsula (SB-12-14).

Garnet crystals are commonly zoned in these samples, potentially recording a polyphase history of Knoydartian and subsequent Caledonian metamorphic events (Supplementary Fig. 1). Mineral chemical analyses on samples SB-12-10B, SB-12-03A, and SB-12-14 (Table 2) utilized a Cameca SX-50 microprobe with a beam current of $20 \mathrm{nA}$ and an acceleration voltage of $15 \mathrm{kV}$ in the Electron Microprobe Lab, Department of Geosciences, Virginia Tech. Bulk rock compositions for samples SB12-10B, MT-12-10, SB-12-03A, and SB-12-14 (Table 3) were obtained for representative 5 gram samples, with all weathered edges removed. The samples were powdered in an aluminum ball mill and passed through $80 \mu \mathrm{m}$ mesh sieve before analysis at the Franklin and Marshall X-ray laboratory using a PANalytical $2404 \mathrm{XRF}$, measuring major element chemistry with titration (for ferric iron estimation) and loss on ignition. 
Rim-core zoning of garnet crystals was quantified in terms of variation in almandine, spessartine, pyrope, and grossular components. Point analyses were conducted on biotite, muscovite, and plagioclase grains. For all samples, little compositional variability was observed in biotite, muscovite or plagioclase; thus, average compositions were used for average P-T calculations (Table 2) with THERMOCALC ver. 3.33 (Powell and Holland, 1994). Bulk rock compositions for samples SB-12-10B, MT-12-10, SB-12-03A, and SB-12-14 were used for P-T pseudosection modeling based on the Holland and Powell (1998 - with 2004 update) data set. Free energy minimizations utilized Perple_X (Connolly, 1990, 2005) with mineral solution models for biotite (Powell and Holland, 1999), garnet (White et al., 2005), feldspar (Furman and Lindsley, 1988), muscovite (Coggon and Holland, 2002), chlorite, (Holland et al., 1998), staurolite, chloritoid, cordierite (all based on Mahar et al., 1997), and an ideal ilmenite-geikielite-pyrophanite solution. Quartz, Al2SiO5 polymorphs, and rutile were treated as end-member compositions, and the fluid phase was assumed to be pure water.

\subsection{Monazite-xenotime geochronology and trace element analysis}

Analysis of monazite and xenotime was carried out at the University of California at Santa Barbara using a laser ablation split stream (LASS) inductively couple plasma mass spectrometry system (Kylander-Clark et al., 2013). U-Th-Pb isotopic measurements were made with a Nu Instruments Plasma HR multicollector ICP-MS and trace elements were measured on an Agilent 7700s quadrupole ICP-MS. Data were collected in situ from thin sections with an $8 \mu \mathrm{m}$ laser spot diameter. All ages are reported with an absolute uncertainty of $2 \sigma$. Compositional maps of monazite and xenotime were made using wavelength dispersive spectrometry (WDS) on Cameca SX-50 microprobes at both the University of Massachusetts, Amherst and Virginia Tech. WDS images of $Y$, $\mathrm{Th}, \mathrm{Ca}, \mathrm{U}, \mathrm{Nd}$, and Gd zoning guided LASS spot placement to minimize mixing between compositionally distinct domains. The 44069 (Aleinikoff et al., 2006) and Bananeira (Kylander-Clark et al., 2013) reference monazites were used for $\mathrm{U}-\mathrm{Th}-\mathrm{Pb}$ and trace element analysis, respectively. Iolite v2.5 was used to reduce the data (Paton et al., 2011). Analyses of the Bananeira secondary reference monazite $(512 \mathrm{Ma}$ ) have a U-Pb weighted average of $511 \pm 1 \mathrm{Ma}(\mathrm{MSWD}=0.98, \mathrm{n}=33$ ).

\section{Mineral assemblages, microstructures, and quartz c-axis fabrics}

\subsection{Meall an t-Sithe (MAT) klippe - Moine thrust sheet}

A geologic map and cross section for the Sgurr Beag klippe exposed on MAT, together with sample locations, are shown in Fig. 3. Micrographs and quartz c-axis fabrics for samples collected from the Moine and Sgurr Beag thrust sheets exposed on MAT are shown in Fig. 4. Sample MT-12-15, a quartz + plagioclase + biotite + muscovite + garnet psammite (Fig. 4) was collected to the southeast of Creag Rainich in the uppermost part of the Moine thrust sheet at $145 \mathrm{~m}$ beneath the SBT (Fig. 3). Muscovite defines a weakly developed foliation. Many of the quartz grain boundaries are annealed, as indicated by the $\sim 120^{\circ}$ angles between grain boundaries. Relict recrystallized quartz grains are smaller (average $80 \mu \mathrm{m}$ ) than those found in the immediate hanging wall to the SBT (discussed below), suggesting that SGR was dominant prior to static recovery, and elongate dynamically recrystallized grains are oblique to main foliation. The quartz c-axis fabric in sample MT-12-15 is a slightly diffuse (maximum density of 4.5 times uniform) asymmetric Type 1 cross girdle (sensuLister and Hobbs, 1980), with a top-to-the-northwest shear sense (Fig. 4). This shear sense is confirmed by the presence of shear bands and elongate recrystallized quartz grains with long axes (Sb) oriented oblique to the macroscopic foliation. 


\subsection{Meall an t-Sìthe - Sgurr Beag klippe}

Sample SB-12-10B is a garnet-rich pelite with muscovite + biotite + quartz + plagioclase + garnet + sulfides (Fig. 4) collected from the summit peak of Creag Rainich, $50 \mathrm{~m}$ above the SBT (Fig. 3). Garnet and phyllosilicates are coarse-grained. Recrystallized quartz grains (average $145 \mu \mathrm{m}$ ) are larger than those in sample MT-12-15 from the underlying Moine thrust sheet and dominated by GBM. Plagioclase has lobate grain boundaries suggesting at least limited plasticity of feldspar at this structural position. The quartz c-axis fabric is a diffuse (maximum density of 3.0 times uniform) Type 2 cross girdle (Fig. 4).

\subsection{Loch Glascarnoch - Moine thrust sheet}

Samples collected along the eastern edge of Loch Glascarnoch (Fig. 1, Fig. 2) range from psammite to pelite, with varying degrees of foliation and lineation development. Recrystallization of quartz by GBM is dominant in samples MT-12-09, MT-12-11 and MT-12-13, with preservation of some microstructural evidence for recrystallization by SGR (Fig. 5). In MT-12-11 multiple generations of foliations are preserved (Fig. 5e) and could represent either discrete deformation events or synchronous formation (main foliation, shear bands, oblique grain shape alignments) during a single shearing event. Plagioclase behaves rigidly in this suite of samples and sericitic alteration is common. Pelitic samples show an increase in the abundance of small subgrains of quartz and possible bulging on feldspar grain boundaries. The psammite units have a higher percentage of straight edge grain boundaries in quartz grains, suggesting static grain boundary recovery. The quartz c-axis fabric for sample MT-12-09 is a diffuse (maximum density of 4.5 times uniform) Type 1 cross girdle with a top to the NW shear sense (Fig. 5). Sample MT-12-11, approximately $1 \mathrm{~km}$ SE of sample MT-12-09, has a strongly defined quartz c-axis fabric (maximum density of 8 times uniform) with a top to the NNW shear sense. Sample MT-12-13, approximately $1 \mathrm{~km}$ SE of sample MT-12-11, has a more diffuse quartz c-axis fabric (maximum density of 3.5 times uniform) with a top to the NNW shear sense. Further discussion of the kinematics indicated by structures preserved in the Loch Glascarnoch region is presented elsewhere (Law et al., 2017 and in prep).

\subsection{Ben Wyvis/Garve area - Moine thrust sheet}

A geologic map and cross section for the Ben Wyvis/Garve area, including sample locations for the Moine and Sgurr Beag thrust sheets, is shown in Fig. 6. In the upper part of the Moine thrust sheet exposed in this area foliation dips to the $\mathrm{SE}$, while associated mineral stretching lineations plunge to the south (Fig. 6a). Lineations for the Moine thrust sheet shown in Fig. 6 are taken from Grant and Harris (2000), as the samples used in this study did not exhibit visible grain shape lineations, although maximum principal finite stretching directions can be indirectly inferred from the quartz caxis fabrics (Fig. 7).

The structurally lowest sample in this area, a quartz + biotite + plagioclase + muscovite + epidote psammite (MT-12-03; Fig. 7k) was collected $190 \mathrm{~m}$ below the SBT (Fig. 6). Biotite, muscovite, and epidote define a macroscopic foliation, with elongate dynamically recrystallized quartz. Lobate grain boundaries and undulose extinction in plagioclase indicate the operation of limited crystal plastic deformation of feldspar. Recrystallization in quartz is dominantly by GBM, with deformation bands within grains indicating overprinting lower temperature deformation. The quartz c-axis fabric is a well-defined (maximum density of 5 times uniform) asymmetric Type 1 cross girdle, with a top-tothe-south shear sense indicate by external fabric asymmetry (Fig. 7e).

Sample MT-12-02 is a quartz + biotite (chloritized) + muscovite + microcline psammite (Fig. $7 \mathrm{j})$ collected $120 \mathrm{~m}$ below the SBT. Foliation is defined by biotite and muscovite, with mica grains 
occasionally tilted up from the macroscopic foliation. Recrystallization in quartz is by GBM overprinted by deformation bands within grains. Lobate grain boundaries are present in microcline indicating limited crystal plastic deformation of feldspar. The quartz c-axis fabric is a well-defined (maximum density of 5.5 times uniform), asymmetric Type 1 cross girdle, with a top-to-the-north shear sense indicated by external fabric asymmetry (Fig. 7d).

Sample MT/SB-12-05 is located 70m below the SBT and is a quartz + plagioclase + biotite + muscovite + microcline psammite (Fig. 7i). The foliation is defined by phyllosilicates and elongate quartz grains. GBM is the dominant quartz recrystallization mechanism, and larger quartz grains exhibit undulose extinction. The quartz c-axis fabric in sample MT/SB-12-05 is a well-defined (maximum density of 5.5 times uniform) asymmetric Type 1 cross girdle, with a weakly defined top-to-the-south shear sense indicated by external fabric asymmetry (Fig. 7c).

\subsection{Ben Wyvis/Garve area - Sgurr Beag thrust sheet}

In the lower part of the Sgurr Beag thrust sheet exposed in this area foliation dips to the SE, while associated mineral stretching lineations plunge to the SSW (Fig. 6). Photomicrographs and quartz caxis fabrics for samples collected from the Sgurr Beag thrust sheet in the Ben Wyvis/Garve area are shown in Fig. 7. Sample SB-12-04 is from a tectonic unit mapped as Lewisian gneiss (Grant and Harris, 2000). SB-12-04 contains quartz + plagioclase + microcline + biotite + muscovite + epidote (Fig. 7h) and was collected at $26 \mathrm{~m}$ above the SBT (Fig. 6b). Foliation is defined by biotite and epidote. Biotite shows evidence of retrogression, and muscovite grains typically cross-cut the macroscopic foliation. Shear bands dominantly indicate a top-to-the-south shear sense. GBM appears to be the dominant quartz recrystallization mechanism, while subgrains are abundant suggesting the role of SGR. Subgrains are also present in plagioclase, and microcline exhibits lobate boundaries indicating at least limited plastic deformation of feldspar. The quartz c-axis fabric in SB12-04 is a well-defined (maximum density of 5.5 times uniform) asymmetric Type 1 cross girdle, with a top-to-the-south shear sense indicated by external fabric asymmetry (Fig. 7b).

Sample SB-12-03A is a plagioclase + quartz + biotite + muscovite + garnet pelite (Fig. 7g) collected $340 \mathrm{~m}$ above the SBT (Fig. 6). Foliation is strongly defined by biotite and muscovite. Plagioclase exhibits microstructural signs of plastic deformation, such as lobate grain boundaries. Quartz grains commonly exhibit undulose extinction and deformation bands, with grain boundaries pinned by phyllosilicates. Lobate grain boundaries are occasionally preserved between adjacent quartz grains. A top-to-the-north shear sense is indicated by biotite-rich shear bands.

Sample SB-12-02 is a quartz + plagioclase + biotite + garnet psammite (Fig. 7f) collected $460 \mathrm{~m}$ above the SBT (Fig. 6). A weakly develop foliation is defined by biotite. Plagioclase grain boundaries are lobate, and GBM is dominant in the quartz grains. Some quartz grain boundaries approach $120^{\circ}$ equilibrium positions suggesting either static annealing or rapid grain boundary recovery to a low energy configuration during plastic deformation. Internally, quartz has strongly developed deformation bands. No unequivocal microstructural shear sense indicators were observed. The quartz c-axis fabric in sample SB-12-02 is a well-defined (maximum density of 6.0 times uniform) asymmetric Type 1 cross girdle, with a weak top-to-the-north shear sense indicated by external fabric asymmetry (Fig. 7a).

\subsection{Creich Peninsula - Moine thrust sheet}

A geologic map for the coastal exposure of the SBT on the Creich Peninsula, adapted from Grant and Harris (2000) and Strachan et al. (2010b), together with sample locations for the Moine and Sgurr Beag thrust sheets is shown in Fig. 8. The foliation in upper parts of the Moine thrust sheet dips to 
the $\mathrm{SE}$, with visible lineations plunging to the SE. MT-12-22 is a quartz + feldspar psammite with minor biotite + chlorite + muscovite + oxides and retrogressed garnet. Subgrain rotation (with some GBM) is the dominant dynamic recrystallization mechanism in quartz (Fig. 9). Many quartz grains show signs of annealing. Sample MT-16-03 is located $\sim 25 \mathrm{~m}$ structurally below the SBT plane as mapped by Grant and Harris (2000). It is a quartz + feldspar psammite with minor muscovite + biotite + chlorite + apatite. Feldspar is commonly heavily sericitized. Both quartz and feldspar have very sinuous grain boundaries, indicating significant grain boundary mobility. Plastically deformed feldspar has a distinct grain shape fabric. These relatively high temperature microstructures contrast with the relatively small quartz fabric opening angle for sample MT-16-03 (see below). However, quartz occasionally has patchy extinction and deformation twins, possibly suggesting a lower deformation temperature overprint. The quartz $\mathrm{c}$-axis fabrics measured for sample MT-16-03 is an asymmetric Type 1 cross girdle, with a weakly defined trailing edge, indicating a top to the ESE shear sense (Fig. 9). This shear sense interpretation is supported by the presence of shear bands and a weakly defined alignment $(\mathrm{Sb})$ of elongate recrystallization quartz grains oblique to the main foliation (Fig. 9).

\subsection{Creich Peninsula - Sgurr Beag thrust sheet}

The Sgurr Beag thrust sheet exposed on the Creich Peninsula is defined by the Glenfinnan group pelite and psammites, with foliation dipping to the SE. Visible lineations plunge to the SE (Fig. 8). Sample SB-12-13 is a quartzite with minor feldspar, biotite and chlorite. Feldspar is heavily sericitized. Quartz grain boundaries are typically sinuous, indicating grain boundary migration recrystallization. Straight quartz grain boundaries, likely produced during annealing, are also present. A weak foliation is defined by the alignment of biotite and chlorite. No microstructural shear sense indicators were observed. The quartz c-axis fabrics (Fig. 9a) consists of two-point maximum fabric close to lineation, with more diffuse small girdle components centered on the lineation and pole to foliation, and an opening angle of $104^{\circ}$ measured over the foliation pole.

Sample SB-12-14 is a

quartz + plagioclase + muscovite + biotite + garnet + staurolite + ilmenite + apatite pelite. Rare staurolite occurs as small tabular grains in micaceous domains. Garnet is commonly retrogressed and replaced or pseudomorphed by quartz + plagioclase + biotite. Muscovite and biotite define the foliation and predominantly pin quartz fabric development. The foliation commonly wraps around garnet and larger plagioclase porphyroclasts. Mica-rich shear bands locally indicate either top-tothe-NW or SE shear senses. Quartz is dynamically recrystallized with lobate quartz-quartz grain boundaries indicating dominant GBM recrystallization, but internally also display patchy extinction and low angle tilt boundaries suggesting a component of lower temperature deformation. However, some of these feldspar augen internally display undulose extinction, subgrains, and occasional lobate grain boundaries, indicating a component of higher temperature plastic deformation (Fig. 9b).

\section{Deformation temperatures}

In and below the MAT klippe, quartz c-axis fabric opening angles indicate that deformation temperatures increase up section from $\sim 460{ }^{\circ} \mathrm{C}$ (sample MT-12-15) in the footwall to the SBT to 550 ${ }^{\circ} \mathrm{C}$ (sample SB-12-10B) in the immediately overlying hanging wall (Fig. 4). Within the central/upper part of the Moine thrust sheet along Loch Glascarnoch, deformation temperatures determined with the c-axis opening range from $545^{\circ} \mathrm{C}$ to $605^{\circ} \mathrm{C}$. Quartz recrystallization microstructures (Stipp et al., 2002) suggest deformation temperatures of $\sim 500^{\circ} \mathrm{C}$ for the samples within the Moine thrust sheet along Loch Glascarnoch (Fig. 5). In the Ben Wyvis/Garve area fabric opening angles (Fig. 7) indicate that deformation temperatures slightly increase up section from $528^{\circ} \mathrm{C}$ to $538^{\circ} \mathrm{C}$ in the footwall to 
the SBT and $545^{\circ} \mathrm{C}$ to $583^{\circ} \mathrm{C}$ in the hanging wall to the SBT. The fabric opening angle of the one sample measured in the footwall to the SBT on the Creich Peninsula suggests deformation temperatures of $\sim 470-500{ }^{\circ} \mathrm{C}$ (Fig. 9), which contrasts with the presumably higher temperature GBM microstructures observed in quartz and feldspar in this sample. This range in estimated deformation temperature is due to the poorly defined trailing edge of the fabric. In the hanging wall to the SBT on the Creich Peninsula the large quartz c-axis fabric opening angle indicates an approximate deformation temperature of $680^{\circ} \mathrm{C}$ using the opening angle thermometer of Faleiros et al. (2016) and employing their 4-6 kbar opening angle curve, as indicated by thermobarometry for adjacent sample SB-12-14 (see below).

\section{Mineral chemistry and metamorphic pressure-temperature estimates}

\subsection{P-T conditions from mineral chemistry}

P-T conditions were first constrained with THERMOCALC; average P-T mode using garnet, biotite, plagioclase and white mica composition for samples from the Sgurr Beag thrust sheet (Table 2), yielding pressures ranging from $6.4 \pm 1.4$ kbar (SB-12-10B; Sgurr Beag klippe on MAT) to $5.1 \pm 1.5$ kbar (SB-12-14; Creich Peninsula). These pressures correspond to temperatures of 565 and $610{ }^{\circ} \mathrm{C}$, respectively. Based on garnet zoning (Fig. 10), we infer that garnet rims most likely preserve the peak metamorphic conditions these rocks experienced, with minimal subsequent intragranular diffusion and exchange reaction. Thus, using the garnet rim composition and the average biotite composition (Table 2), the Ferry and Spear (1978) thermometer yields temperatures of $610 \pm 50{ }^{\circ} \mathrm{C}$, $590 \pm 50^{\circ} \mathrm{C}$, and $660 \pm 50{ }^{\circ} \mathrm{C}$ (SB-12-10B/MAT, SB-12-03A/Ben Wyvis-Garve, and SB-12-14/Creich Peninsula, respectively). It is likely at the highest of these temperatures that garnet core compositions have been somewhat modified by post-growth intra-crystalline diffusion (Yardley, 1977; Florence and Spear, 1991; Caddick et al., 2010), rendering crystal cores unsuitable for accurately constraining prograde conditions. P-T results for each method and sample are summarized in Table 4.

\subsection{P-T conditions from pseudosections}

To further quantify the possible P-T range associated with metamorphism, pseudosections were calculated from bulk rock chemistry for sample MT-12-10 from Loch Glascarnoch in the upper part of the Moine thrust sheet (Supplementary Fig. 2), and for samples SB-12-10B (Supplementary Fig. 3), SB-12-03A (Fig. 11), and SB-12-14 (Fig. 12), from the MAT klippe, Ben Wyvis/Garve, and Creich Peninsula localities in the lower part of the Sgurr Beag thrust sheet (Table 3). The P-T range within these pseudosections that is consistent with observed mineral assemblages is large, but the approximate abundances of phases restricts the likely P-T range of stability. Observed mineral abundances were obtained from point-counting thin sections, and are shown with an uncertainty of 2\% (Fig. 11, Fig. 12). Pseudosection modeling only gives a best estimate for metamorphic conditions, as there are unquantified uncertainties from point counting, sample heterogeneity, and bulk rock composition that are not considered in these estimates. Furthermore, calculations assume sustained sample-wide equilibrium without considering kinetic factors that may play an important role in controlling textures and mineral compositions associated with specific metamorphic reactions (e.g. Carlson et al., 2015).

The P-T range for sample MT-12-10 from the Moine thrust sheet at Loch Glascarnoch is between 550 and $680^{\circ} \mathrm{C}$ and 2.8 to $7.2 \mathrm{kbar}$ (Supplementary Fig. 2) using calculated and observed mineral abundances, which serves as a best estimate of likely metamorphic conditions preserved in this 
thrust sheet. We cannot better constrain the broad estimated pressure range with the observed mineral assemblage (muscovite + quartz + plagioclase + biotite + garnet). Biotite abundances confine the upper pressure range, but no other mineral phases are present that can improve the lower pressure estimates. Temperature is best constrained by the abundance of muscovite and plagioclase. More meaningful pressure constraints for MT-12-10 may come from the presence of kyanite overprinting andalusite in the contact aureole of the Carn Chuinneag granite, located approximately $15 \mathrm{~km}$ to the NE of Loch Glascarnoch in the upper part of the Moine thrust sheet (Fig. 1; Peach et al., 1912; Tilley, 1935; Harker, 1953, 1954; Shepherd, 1973; Wilson and Shepherd, 1979). Growth of kyanite is interpreted to be associated with regional metamorphism and fabric formation that post-dates intrusion of the granite and may structurally and temporally correlate with the deformation fabrics that we have described in our samples from Loch Glascarnoch (Krabbendam et al., 2011). Assuming temperatures in the $550-680^{\circ} \mathrm{C}$ range for MT-12-10, potential correlation with the kyanite-bearing deformation fabrics around the Carn Chuinneag granite (Fig. 1) suggests minimum pressures of approximately $4.8-7.2 \mathrm{kbar}$.

Sample SB-12-10B, from the Sgurr Beag klippe on MAT, has the highest garnet abundance of the samples analyzed and, together with biotite abundance, constrains P-T conditions to $615-645^{\circ} \mathrm{C}$ and 6.4-7.4 kbar (Supplementary Fig. 3). The pseudosection calculations fall within error of both the garnet-biotite thermometer at $610 \pm 50{ }^{\circ} \mathrm{C}$ and THERMOCALC calculated P-T conditions of $565 \pm 50$ ${ }^{\circ} \mathrm{C}$ and $6.4 \pm 1.4 \mathrm{kbar}$.

In the immediate hanging wall to the SBT near Garve (Fig. 6), sample SB-12-03A has both mineral assemblages consistent with equilibration in a narrow T range of $595-625^{\circ} \mathrm{C}$ (Fig. 11) and garnetbiotite thermometry temperatures (Ferry and Spear, 1978) of $590 \pm 50^{\circ} \mathrm{C}$. Pressures range from 5.6 to $7.7 \mathrm{kbar}$, based on plagioclase, biotite, muscovite, quartz, and garnet abundances. Plagioclase, quartz and biotite form rims around some garnet grains in this sample, which is interpreted as a garnet breakdown texture (also at the expense of muscovite). Therefore, we consider pressure constraints from this sample to be a minimum.

The pseudosection calculated for SB-12-14 from the Creich Peninsula indicates a P-T range for equilibration at $540-635^{\circ} \mathrm{C}$ and $3.6-6.0 \mathrm{kbar}$ (Fig. 12), fitting the observed

staurolite + plagioclase + muscovite + ilmenite + biotite + garnet + quartz mineral assemblage. Observed mineral abundances shrink this P-T window to $600-615^{\circ} \mathrm{C}$ and $5.6-6.1 \mathrm{kbar}$, predominantly constrained by staurolite and plagioclase abundances. This temperature range is cooler but within uncertainty of the temperature predicted by garnet-biotite thermometry $660 \pm 50$ $\left.{ }^{\circ} \mathrm{C}\right)$. P-T conditions predicted by THERMOCALC are within the range of the mineral abundances from pseudosection modeling, at $610 \pm 50^{\circ} \mathrm{C}$ and $5.1 \pm 1.4$ kbar.

\section{Monazite-xenotime geochronology and thermometry for Sgurr}

\section{Beag thrust sheet}

Within the study areas, monazite and xenotime grains were only found in samples from the Sgurr Beag thrust sheet. In the Moine thrust sheet, only pseudomorphs, highly altered, very fine grained REE phases and retrogressed former monazite are occasionally found.

Monazite and xenotime exhibit a consistent paragenetic relationship with garnet in most of the samples from the Sgurr Beag thrust sheet (Fig. 13). In samples SB-12-10B (MAT) and SB-12-03A (near Garve), small $(5-10 \mu \mathrm{m})$ xenotime inclusions are commonly found in garnet cores, while $(10-30 \mu \mathrm{m})$ monazite is present in garnet rims. Out of 28 monazite grains examined, 6 are matrix hosted and 22 are included in garnet, 20 of which are in garnet rims. All examined xenotime grains were included in 
garnet cores $(n=44)$. Garnet cores in sample SB-12-03A are defined by abundant inclusions of quartz, apatite, and rutile (Fig. 13c, d, e), with monazite occurring at the outer edges of more inclusion poor mantles. Garnet cores in sample SB-12-10B are also marked by a higher abundance of quartz, apatite, ilmenite, and rutile than in mantles. Monazite grains are found both immediately inward and outward of a ring of large quartz inclusions at the margin of the mantles (Fig. 13a, b, f). The consistency with which xenotime inclusions are found in garnet cores and monazite occurs in rims suggests that at least some of the garnet growth in these samples is bracketed by xenotime and monazite stability. This consistent inclusion pattern is unlikely if monazite and xenotime both predated garnet.

In contrast, monazite and xenotime from sample SB-12-14 (Creich Peninsula) do not exhibit a consistent inclusion relationship with garnet. Unlike samples from the MAT and Ben Wyvis/Garve areas, this sample is extremely monazite-rich, with 100 + grains in the matrix of a single thin section and only 3 grains included in garnet. Apatite is abundant and commonly overgrown by irregular and globular monazite. Of the ten xenotime grains identified, two were included in a garnet core but were too small to successfully date. The relative age of garnet growth in this sample is thus ambiguous and it should be noted that polyphase garnet growth cannot be ruled out in this or other samples and would be difficult to definitively identify without direct garnet geochronology (Baxter et al., 2017).

Isotope data (Supplementary Table 1) yielded exclusively Precambrian ages for monazite and xenotime inclusions within garnet in samples SB-12-10B (Sgurr Beag klippe on Meal an t-Sithe) and SB-12-03A (Sgurr Beag thrust sheet near Ben Wyvis/Garve), and both phases have experienced significant $\mathrm{Pb}$ loss. The ages imply significant garnet growth and metamorphism during Knoydartian events; however precise timing constraints are elusive. Sample SB-12-10B yields concordia intercepts at $866 \pm 110 \mathrm{Ma}$ and $576 \pm 110 \mathrm{Ma}$ (MSWD = 1.14) (Fig. 14a), while monazite analyses from sample SB-12-03A give upper and lower intercept ages of $819 \pm 49 \mathrm{Ma}$ and $532 \pm 54 \mathrm{Ma}$ (MSWD = 1.5). Xenotime ages cluster around $\sim 675 \mathrm{Ma}$, but fall close to the Pb loss tread (Fig. 14b). Xenotime is notably younger than most of the monazite, which contradicts expectations for xenotime found in garnet cores and possibly indicates that small $(5-10 \mu \mathrm{m})$ xenotime grains were more susceptible to isotopic disturbance. Matrix monazite is isotopically indistinguishable from garnet-included monazite. In both of these samples, many analyses are less than $\pm 10 \%$ discordant and a significant number cluster at c. 750-740 Ma. Given the high uncertainty on the intercept ages, crystallization at c. $750 \mathrm{Ma}$ followed by isotopic resetting at 600-550 Ma is the most robust interpretation.

Two distinct populations of monazite in sample SB-12-14 from the Creich Peninsula represent Caledonian and Knoydartian events. Precambrian monazite is present both as inclusions within garnet and in the surrounding matrix. Like samples from the MAT and Ben Wyvis/Garve areas, there is a significant Pb-loss trend (Fig. 14c and d). No Scandian ages were obtained for monazite inclusions in garnet and all dated xenotime in this sample is Scandian. A linear regression of all SB12-14 data (Fig. 14c and d) yields a poor fit ( $768 \pm 58 \mathrm{Ma}$ and $386 \pm 18 \mathrm{Ma}$, MSWD = 7.3), so Scandian and Precambrian populations are treated separately. Scandian monazite seems to show a trend of common lead incorporation, and gives an intercept age of $420 \pm 3 \mathrm{Ma}$ (MSWD $=2.0$ ). Weighted averages of xenotime and concordant (90-110\%) monazite analyses are $420 \pm 4 \mathrm{Ma}$ (MSWD =1.0) (Figs. 14e) and $422 \pm 2 \mathrm{Ma}$ (MSWD = 1.3), respectively. A regression of exclusively Precambrian analyses (Fig. 14c) yields intercept ages of $541 \pm 27 \mathrm{Ma}$ and $909 \pm 65 \mathrm{Ma}$ (MSWD = 1.2).

Scandian monazite analyses in sample SB-12-14 from the Creich Peninsula show a distinctly shallower Eu anomaly relative to Precambrian monazite (Fig. $14 \mathrm{f}$ and $\mathrm{g}$ ). This could result from 
plagioclase breakdown during retrograde metamorphism or a second phase of lower P-T metamorphism with less plagioclase in the stable assemblage (see Fig. 12). Alternatively, a change in the redox state of Eu could produce a similar pattern (e.g. Kohn, 2016).

The composition of monazite in equilibrium with xenotime can be used to calculate equilibration temperature (Heinrich et al., 1997; Pyle et al., 2001), with temperatures calculated here for Scandian age monazite from sample SB-12-14. Given that the weighted mean ages of monazite and xenotime populations are within uncertainty of one another, monazite is interpreted to have grown in equilibrium with xenotime. Monazite is far more abundant than xenotime, so it is possible that any equilibrium is only local and monazite is under-saturated in YPO4. In this case, calculated temperatures would represent a minimum. Analyzed monazite has an average molar composition of $\mathrm{XCheralite}=0.017, \mathrm{XBrabantite}=0.047, \mathrm{XY}+\mathrm{HREE}=0.072$ and $\mathrm{XLREE}=0.864$. Calculated temperatures using the Pyle et al. (2001) and Heinrich et al. (1997) calibrations are $525 \pm 20^{\circ} \mathrm{C}$ and $610 \pm 20^{\circ} \mathrm{C}$, respectively, with stated uncertainty representing just the internal uncertainty of the trace element analyses. These temperatures are in broad agreement with calculated peak temperatures from pseudosection modeling $\left(600-620^{\circ} \mathrm{C}\right.$ ). The Heinrich et al. (1997) calibration is in much better agreement with silicate phase equilibria calculations, as has been noted in previous studies (Tomkins and Pattison, 2007; Daniel and Pyle, 2006). However, the Pyle et al. (2001) temperature of $525 \pm 20^{\circ} \mathrm{C}$ would still agree with an interpretation of retrograde monazite growth during plagioclase breakdown. Thus, monazite ages in sample SB-12-14 from the Creich Peninsula are here associated with peak or post-peak Scandian temperatures. Metamorphic conditions for the Sgurr Beag thrust sheet exposed on the Creich Peninsula, constrained by thermometry and pseudosection analyses could be associated with Scandian, Grampian, or Knoydartian tectonism.

\section{Discussion}

\subsection{P-T correlation between study areas}

This study found that microstructures in the upper part of the Moine thrust sheet and the lower part of the overlying Sgurr Beag thrust sheet record deformation temperatures that range between 460 ${ }^{\circ} \mathrm{C}$ and $680^{\circ} \mathrm{C}$, with cooler Td in the footwall to the SBT (Fig. 15). Peak metamorphic temperatures from pseudosection analysis and garnet-biotite thermometry are within error of $\mathrm{Td}$, and do not vary significantly across the study region. Xenotime and monazite petrochronology indicate that peak metamorphism is associated with the Knoydartian orogenic event (840-720 Ma), with reworking during Scandian thrusting (445-425 Ma).

Between the north coast and Assynt (Fig. 1), Thigpen et al. (2013) and Law (2014, his Fig. 24) showed that temperatures associated with Scandian (435-425 Ma) thrust-related shearing increase from the Moine thrust eastwards through the Moine and Ben Hope thrust sheets into the Naver sheet. In the immediate hanging wall of the Naver thrust, Td indicated by quartz fabric opening angles $\left(655^{\circ} \mathrm{C}\right)$ were very similar to Tm indicated by garnet-biotite thermometry $\left(645^{\circ} \mathrm{C}\right.$; Barr et al., 1986) in samples from adjacent outcrops. These estimates are very similar to those obtained here from further to the south in the immediate hanging wall of the SBT in the MAT klippe of the Fannich Mountains (Fig. 3), based on both pseudosection (615-645 ${ }^{\circ} \mathrm{C}$ at 6.4-7.4 kbar; Supplementary Fig. 3) and fabric opening angle $\left(550^{\circ} \mathrm{C}\right.$; Fig. 4 ) analyses. Temperature and pressure estimates from this most foreland-positioned exposure of the Sgurr Beag thrust sheet (Fig. 1) in the Fannich Mountains are also very similar to those in the immediate hanging wall of the SBT exposed on the Creich Peninsula (600-615 ${ }^{\circ} \mathrm{C}$ at 5.6-6.1 kbar; Fig. 12) located $60 \mathrm{~km}$ to the east of the Fannichs (measured parallel to an assumed WNW transport direction on the underlying Moine thrust zone, Fig. 1). In the 
immediate hanging wall of the SBT near Ben Wyvis/Garve (Fig. 6), Tm is between $\sim 595$ and $625^{\circ} \mathrm{C}$, and $\mathrm{Td} \sim 580^{\circ} \mathrm{C}$.

These data suggest that penetrative shearing in the Sgurr Beag thrust sheet occurred at broadly similar crustal depths and temperatures in the three study areas. Kelley and Powell (1985) noted that thrust-related shearing in the Fannichs occurred during metamorphism, and at minimum temperatures consistent with biotite recrystallization. Our P-T conditions across the Sgurr Beag thrust sheet support the conclusion that deformation was synchronous with metamorphism. Perhaps more surprising is the similarity in estimated P-T conditions for the immediate hanging wall to the SBT exposed in extreme foreland (MAT klippe) and hinterland (Creich Peninsula) positions: intuitively it might be expected that peak P-T conditions towards the foreland would be significantly lower than those in the hinterland.

\subsection{Relative ages of thrusting, folding, penetrative shearing/fabric formation}

The now eroded westward continuation of the SBT (locally preserved in the MAT and Fannich klippen) is clearly folded around a series of west-vergent antiforms and synforms defined by lithotectonic units (Krabbendam et al., 2011) in the underlying Moine thrust sheet (Fig. 2). These folds have N-S trending gently plunging hinges and hinge planes that progressively steepen eastwards along the transect (Krabbendam et al., 2011). The structural relationship between these $\mathrm{km}$-scale west-vergent folds and the underlying (unexposed) Moine thrust is unknown, although it seems at least structurally plausible that they are broadly synchronous with top to the WNW motion on the Moine thrust, and may therefore detach on to the underlying Moine thrust plane. This in turn suggests that shearing on the Moine thrust is younger than (or outlasted) motion on the overlying SBT, but leaves unanswered the relative and absolute ages of penetrative deformation and metamorphism in the Moine and Sgurr Beag thrust sheets that predate km-scale folding.

At the base of the Moine thrust sheet on the NW end of the transect through our study areas (Fig. 2) the Moine psammites are deformed into platy mylonite that dips gently to the ESE, parallel to the underlying Moine thrust. Above this mylonite is a $\sim 4 \mathrm{~km}$ thick planar zone of intense shearing, in which gently plunging mineral stretching lineations change in trend from $E$ to SSE when traced structurally upwards and to the SE (Krabbendam et al., 2011; their Fig. 3). This is accompanied by a change in grain shape fabrics which become less platy and more granular. Above this mylonite and shear zone, the metasedimentary rocks of the Moine and overlying Sgurr Beag thrust sheets are buckled into the above-mentioned km-scale folds. Mineral stretching lineations on the penetrative grain shape foliations here are sub-parallel to the N-S gently plunging fold hinges, potentially indicating that these grain shape lineations/foliations developed during formation of the westvergent folds. However, in fold hinge zones it can be demonstrated that this tectonic foliation is deformed around these km-scale folds (Law et al., 2017). For example, in the hinge zone of the Braemore syncline (Fig. 2) the tectonic foliation containing the N-S trending lineation is gently dipping and clearly folded around the gently south-plunging fold hinge. Similarly, in the hinge zone of the adjacent Beinn Dearg anticline (Fig. 2) the foliation is folded about outcrop-scale folds with $\mathrm{N}$ $S$ trending gently plunging hinges.

In the planar mylonite zone above the Moine thrust, microstructures and quartz c-axis fabrics indicate a top to the WNW to NW shear sense (Law et al., 2017) compatible with regional transport direction on the Moine thrust zone determined elsewhere (e.g. Coward, 1985; Strachan et al., 2002; Butler, 2010; Leslie et al., 2010). However, in the overlying fold zone to the east, microstructures and quartz c-axis fabrics from both the Moine and Sgurr Beag thrust sheets, (Fig. 4, Fig. 5, Fig. 7), indicate a remarkably consistent pattern of top-to-the- $\mathrm{N}\left( \pm 20^{\circ}\right)$ shearing (possible exceptions in Fig. 7) after 
unfolding the $\mathrm{km}$-scale right way-up and inverted fold limbs back to the horizontal (e.g. Krabbendam et al., 2011; Law et al., 2017). Quartz c-axis fabrics in both kinematic domains clearly demonstrate that mineral lineations are parallel to the maximum principal stretching direction. The originally planar subhorizontal kinematic domain of top-to-the-north shearing would have been at least $60 \mathrm{~km}$ wide before later west-vergent folding associated with motion on the underlying Moine thrust (Law et al., 2017). Top-to-the-WNW shearing in the greenschist-facies mylonites in the immediate hanging wall to the Moine thrust at the NW end of the transect is of Scandian (mid-Silurian) age (Kelley and Powell, 1985; Kelley, 1988; Freeman et al., 1998; Goodenough et al., 2011). However, the higher temperature top-to-the-north shearing, preserved in the overlying fold zone to the east, could well be of older Scandian, Grampian (Ordovician) or Knoydartian (Precambrian) age. In the Naver thrust, to the north, similar SSE mineral lineation are interpreted as Scandian due to the $\sim 425 \mathrm{Ma}$ syntectonic, deformed granites (Kinny et al., 2003a; b). However, in the absence of similar syn-tectonic granites in the Sgurr Beag thrust, it is difficult to determine the age of deformation. A Precambrian age for pervasive top-to-the-north shearing would appear to be precluded by the general consensus that the Carn Chuinneag granite (Fig. 1) dated at 594 Ma (Oliver et al., 2008, their Fig. 2) predates formation of the dominant regional metamorphic fabrics (with N-S trending lineations) in the upper/eastern part of the Moine thrust sheet (Johnson and Shepherd, 1970; Shepherd, 1973; Wilson and Shepherd, 1979). However, an episode of deformation that predates the granite has also been recognized (De L'Apparant, 1935; Harker, 1970; Wilson and Shepherd, 1979). There has historically been disagreement about whether garnet grade metamorphism in the Carn Chuinneag aureole was syn-to post-intrusion (Shepherd, 1973; Kelley, 1984) or if an earlier phase of pre-intrusion garnet growth also occurred (De L'Apparant, 1935; Long and Lambert, 1963). Our data from the Sgurr Beag thrust sheet demonstrate Precambrian garnet growth that must predate intrusion of the Carn Chuinneag granite. However, the position of those rocks at the time of Precambrian garnet growth relative to the Moine thrust sheet containing the later granite is unclear.

Microstructural and K-Ar cooling age data from the Fannich Forest area immediately south of samples in this study (Fig. 2, Fig. 3) suggest that penetrative shearing along the base of the Moine thrust sheet is younger than or outlasted penetrative shearing at higher structural levels in the Moine and Sgurr Beag thrust sheets further to the east (Kelley and Powell, 1985; Kelley, 1988, 2009a; 2009b; Butler, 2010; Law and Johnson, 2010). Kelley and Powell (1985) note that in addition to being deformed by younger $\mathrm{km}$-scale folds, the SBT itself reworks earlier structures and fabrics. Kelley and Powell (1985) also suggested that movement on the SBT in the Fannich Forest and MAT area (Fig. 3) was synchronous with metamorphism in its hanging wall and footwall, based on recrystallization of biotite in shear bands associated with thrusting. Microstructures and deformation temperatures observed in our samples support these conclusions. K-Ar data from biotite near MAT (Fig. 3) consistently indicate cooling ages of $421 \pm 3 \mathrm{Ma}$ (Kelley, 1988). Shearing clearly occurred during metamorphic mineral growth and the $\sim 420 \mathrm{Ma}$ cooling ages indicate a minimum age for Scandian thrust-related shearing.

\subsection{Timing of metamorphism and deformation}

Monazite and xenotime ages from the Sgurr Beag thrust sheet indicate that garnet growth in the MAT/Fannich Mountains (sample SB-12-10B; Fig. 3, Fig. 13, Fig. 14a) and Ben Wyvis/Garve (sample SB-12-03A; Fig. 6, Fig. 13, Fig. 14b) areas occurred during the Knoydartian event. This implies that peak metamorphic assemblages preserved in the Sgurr Beag thrust sheet are also Knoydartian, in broad agreement with previous work in this area. Monazite and zircon fractions from the Carn Gorm pegmatite and adjacent host rock in the Ben Wyvis/Garve area have yielded upper and lower intercepts of $740 \pm 8 \mathrm{Ma}$ and $456 \pm 4 \mathrm{Ma}$, respectively (Cawood et al., 2015), indicating Knoydartian 
crystallization followed by early Scandian (post-Grampian) reworking. Monazite in the pegmatite host rock yielded a $454 \pm 1 \mathrm{Ma}$ age; see also Hyslop (1999) for review of earlier isotopic dating work on the Carn Gorm rocks. Zircon geochronology of a sample from Glen Doe (60 km SSW of the Ben Wyvis/Garve area; Fig. 1) yielded very similar results to our monazite data from MAT and near Garve (Cawood et al., 2015). In the Glen Urquhart area, 30 km to the south of sample SB-12-03A from the Ben Wyvis/Garve area (Fig. 1), Cutts et al. (2010) constrained three phases of garnet growth, two of which were Knoydartian. The earliest phase of garnet growth corresponded to metamorphic conditions of $\sim 650^{\circ} \mathrm{C}$ and $7 \mathrm{kbar}$ at $825-780 \mathrm{Ma}$. The second phase recorded peak metamorphism and migmatization at $\sim 700^{\circ} \mathrm{C}, 9 \mathrm{kbar}$ and $724 \pm 6 \mathrm{Ma}$, followed by Grampian garnet growth ( 463 $\mathrm{Ma}$ ) at $650^{\circ} \mathrm{C}$ and $7 \mathrm{kbar}$. Cawood et al. (2015) also note that there appears to be two distinct phases of Knoydartian metamorphism across the NW Highlands at 840-780 Ma and 740-725 Ma. Although our intercept ages correspond to the first phase, most of the concordant analyses correspond to the second phase of Knoydartian orogenesis.

The extent of Caledonian overprinting is uncertain and deformation fabrics in this area may locally be of either Caledonian or Knoydartian age. Garnet growth near the base of the Sgurr Beag thrust sheet in the MAT/Fannich Mountains (sample SB-12-03A) and Ben Wyvis/Garve area (SB-12-10B), respectively, cannot be unequivocally associated with the development of matrix fabrics. It is possible that large upright folds in these areas represent lower temperature Scandian buckling of Precambrian fabrics (see Fig. 2; Krabbendam et al., 2011). The underlying Moine thrust sheet reached at least high enough temperatures to reset K-Ar muscovite and biotite ages at $\sim 425 \mathrm{Ma}$ (Kelley and Powell, 1985; Kelley, 1988, 2009a). It is therefore possible that the structurally higher parts of the Moine thrust sheet and overlying Sgurr Beag thrust sheet, particularly in the foreland part of the Ullapool-Garve area (Fig. 1), did not reach high metamorphic grades during Scandian orogenesis and the 600-650 ${ }^{\circ} \mathrm{C}$ temperatures inferred from metamorphic mineral assemblages and quartz fabrics represent Knoydartian deformation. Although motion on the SBT may have been synchronous with metamorphism (840-720 Ma), our results do not preclude a component of early Scandian deformation and metamorphism at a similar grade. Dating additional monazite and xenotime in garnet bearing samples, as well as further sampling of pelite units, would help to clarify the relationship between garnet growth and deformation, and ultimately the timing of motion along the SBT.

The low-grade Scandian temperature in the west contrasts with data from sample SB-12-14, from the base of the Sgurr Beag thrust sheet on the Creich Peninsula in the east (Fig. 1, Fig. 9), which likely records post-peak Scandian age temperatures of $\sim 60{ }^{\circ} \mathrm{C}$ at $425-420 \mathrm{Ma}$ (Fig. 12, Fig. 14a, d) based on matrix monazite analyses. In the Ben Hope, Naver, and Skinsdale nappes further north (Fig. 1), Scandian deformation and metamorphism appears to have completely overprinted any pre-existing Knoydartian signature (Kinny et al., 2003a; our unpublished data). Scandian metamorphism in these nappes seems to have reached higher temperatures, possibly due to either a greater abundance of 430-425 Ma intrusive bodies or a deeper structural level now being exposed in the northern-most part of the Northern Highlands. Knoydartian (and possibly Grampian) signatures are, however, preserved at higher structural levels now exposed further to the south in the MAT/Fannich Mountains and Ben Wyvis/Garve areas. Similar arguments for the dominance of Knoydartian and Grampian ages in the Caledonides of Shetland have recently been made by Walker et al. (2016) and Lancaster et al. (2017).

The lower intercept ages of 550 Ma for samples SB-12-03A and SB-12-14 (Fig. 14) from the MAT/Fannich Mountains and Ben Wyvis/Garve area, respectively, do not correspond directly to either Scandian or Grampian phases of orogenesis. However, they are broadly similar to, or post- 
date, the ages of several granites within the Skinsdale and Moine nappes. The Berriedale and Braeval granites in the Skinsdale nappe in East Sutherland (Fig. 1) have U-Pb zircon crystallization ages of 599 $\pm 9 \mathrm{Ma}$ and $588 \pm 8 \mathrm{Ma}$, respectively (Kinny et al., 2003b), whereas the Carn Chuinneag granite (Fig.

1) has been dated at $594 \pm 11 \mathrm{Ma}$ (Pidgeon and Johnson, 1974; Pidgeon and Compston, 1992; Oliver et al., 2008). These granites are interpreted to be related to late Neoproterozoic age rifting of the lapetus Ocean (Kinny et al., 2003b) and it is possible that high heat flow and/or fluid flow may have locally perturbed the isotopic signatures of monazite and xenotime.

\subsection{Multiple movements on the SBT}

Grant and Harris (2000) conducted a petrofabrics-based kinematic study in the Ben Wyvis/Garve region, highlighting different senses of movement along the SBT. Several of their observations, such as an increase in foliation intensity towards the thrust, south plunging lineations, and two locally preserved shear senses (top-to-the-north and top-to-the-south), were confirmed in our study. Grant and Harris (2000) suggested that movement along the SBT was accompanied by penetrative shearing extending into the footwall and hanging wall over a total thickness of $\sim 200 \mathrm{~m}$. However, our petrofabric data, e.g. high-density quartz c-axis fabrics with 4-6 times uniform maximum density distribution, suggests that this penetrative shearing occurred in a much thicker zone, extending at least $400 \mathrm{~m}$ into the hanging wall.

Grant and Harris (2000) also suggested that there was a second generation of movement along the SBT in the Ben Wyvis/Garve area, based on top-to-the-south shear sense indicators from quartz fabrics in both the footwall and hanging wall. They interpreted this top-to-the-south shear sense as normal-sense dip-slip, extensional movement that occurred during retrogression and exhumation/cooling. The present study yields similar mixed top-to-the-north and top-to-the-south results from both the immediate footwall and hanging wall of the SBT in the Ben Wyvis/Garve area. Additionally, quartz recrystallization microstructures and fabric opening angles are very similar in samples with top-to-the-north and top-to-the-south shear indicators, suggesting that both phases of motion occurred under similar deformation temperatures $\left(535-545^{\circ} \mathrm{C}\right)$. Within our study area this top-to-the-south shearing is probably only of local significance, as top-to-the-north or NW shear senses are almost ubiquitously recorded (Law et al., 2017) in the Moine and Sgurr Beag thrust sheets along the Braemore Junction - Loch Glascarnoch - Garve transect after restoring the km-scale NW vergent folds (Fig. 1, Fig. 2). However, in the structurally complex Glenelg area, located $70 \mathrm{~km}$ to the SW of Ben Wyvis/Garve in the southern part of the Moine thrust sheet (south of Loch Alsh in Fig. 1), Krabbendam et al. (2018) have documented the presence of broadly south or SSW facing early regional-scale folds of probable Knoydartian age. Top-to-the-south movement could therefore also have developed at a regional scale to the south of our study area.

\section{Conclusions}

Microstructural, quartz petrofabric, microprobe-based petrology, and accessory phase geochronology data from four transects across the immediate hanging wall of the Sgurr Beag Thrust (SBT) and the underlying Moine thrust sheet show that:

1) A regional scale top-to-the-north/northwest shear sense is indicated by both microstructures and quartz c-axis fabrics from the structurally central and upper parts of the Moine thrust sheet and from the immediate hanging wall of the overlying Sgurr Beag thrust sheet exposed (from west to east) on the Meall an T-Sithe (MAT) klippe, along Loch Glascarnoch, and in the Ben Wyvis/Garve area. 
2) Penetrative shearing associated with top-to-the-north/northwest reverse-sense movement along the SBT occurred under amphibolite-facies conditions, with deformation temperatures increasing from footwall to hanging wall. In the most westerly preserved part of the Sgurr Beag thrust sheet, the MAT klippe, quartz c-axis fabric opening angles indicate deformation temperatures of $\sim 460{ }^{\circ} \mathrm{C}$ in the immediate footwall and $\sim 550^{\circ} \mathrm{C}$ in the hanging wall. $35 \mathrm{~km}$ to the ESE in the Ben Wyvis/Garve area, estimated deformation temperatures across the SBT range from $\sim 530$ to $\sim 585^{\circ} \mathrm{C}$. These apparent thermal gradients preserved across the SBT may be as old as Neoproterozoic in age, though if the Carn Chuinneag granite is cut by these penetrative grain shape fabrics associated with formation of the top-to-the-north/northwest quartz c-axis fabrics, they may be younger than 594 Ma.

3) A consistent garnet-xenotime-monazite mineral paragenesis indicates that garnet crystals in the Sgurr Beag nappe are relicts of Knoydartian (840-720 Ma) metamorphism. In the MAT klippe, and Ben Wyvis/Garve areas the age(s) of matrix metamorphic mineral assemblages has yet to be determined. The degree of metamorphic overprinting during Scandian or Grampian reworking is unclear. In contrast, in the Creich Peninsula area, abundant matrix monazite indicates an episode of Scandian (Silurian) metamorphism at temperatures of $\sim 600^{\circ} \mathrm{C}$, while garnet crystals may be of Knoydartian, Grampian or Scandian age.

4) Pseudosection-based analyses indicate that peak metamorphism in the immediate hanging wall to the SBT exposed in the MAT, Ben Wyvis/Garve and Creich Peninsula areas occurred at temperatures of $\sim 600-650{ }^{\circ} \mathrm{C}$ and pressures ranging from $\sim 5.6-7.7 \mathrm{kbar}$. No significant change in peak conditions was found between more foreland (west) and more hinterland (east) exposures of the Sgurr Beag thrust sheet. Peak metamorphic conditions in the central part of the Moine thrust sheet exposed near Loch Glascarnoch are similar to those in the overlying Sgurr Beag thrust sheet. Our strategy of relying primarily on the modal proportion of metamorphic minerals for P-T constraints is less sensitive to re-equilibration than compositionally-based methods, and thus these constraints likely reflect Knoydartian metamorphism.

5) Although P-T estimates from metamorphic petrology and deformation fabric thermometry in the Sgurr Beag nappe are very similar to estimates from northernmost Scotland (Thigpen et al., 2013; Ashley et al., 2015), our geochronology indicates that some phases, particularly garnet, are very different in age. Most metamorphic assemblages and deformation fabrics in the north are likely Scandian (e.g. Kinny et al., 2003a), although in some cases garnet growth in the Moine nappe has been shown to be $\sim 450 \mathrm{Ma}$ or Grampian (Bird et al., 2013). This study shows that mineral assemblages in the Sgurr Beag nappe have components that are as old as Knoydartian. It is difficult to unequivocally link these structural and metamorphic observations with a particular orogenic event. The NW Highlands terrane is an example of the potential pitfalls of assuming that metamorphic assemblages and structural features in an area are contemporaneous solely on the basis of similar metamorphic grade and structural style. Northern Scotland has been affected by at least four (Scandian, Grampian, two phases of Knoydartian), and possibly more, metamorphic events that reached similar P-T conditions.

\section{Acknowledgements}

We are grateful to editor Bill Dunne, guest editor lan Alsop, and reviewers Rob Strachan and Ryan Thigpen for thoughtful comments that helped to improve the manuscript. We also thank Rob Strachan for help with planning sampling locations. We acknowledge funding from the National Science Foundation (grants EAR 1220138, EAR 0711207, and EAR 0538031) to RDL. 


\section{References}

Aleinikoff, J. N., Schenck, W. S., Plank, M. O., Srogi, L., Fanning, C. M., Kamo, S. L. \& Bosbyshell, H., 2006. Deciphering igneous and metamorphic events in high-grade rocks of the Wilmington Complex, Delaware: Morphology, cathodoluminescence and backscattered electron zoning, and SHRIMP U-Pb geochronology of zircon and monazite. Geological Society of America Bulletin, 118(1-2), 39-64.

Ashley, K.T., Thigpen, J.R., Law, R.D., 2015. Prograde evolution of the Scottish Caledonides and tectonic implications. Lithos 224, 160-178.

Barr, D., Holdsworth, R.E., Roberts, A.M., 1986. Caledonian ductile thrusting in a Precambrian metamorphic complex: The Moine of northwestern Scotland. Geological Society of America Bulletin 97, 754-764.

Bird, A.F., Thirlwall, M.F., Strachan, R.A., 2013. Lu-Hf and Sm-Nd dating on metamorphic garnet: evidence for multiple accretion events during the Caledonian orogeny in Scotland. Journal of the Geological Society, 170(2), 301-317.

Bonsor, H., Strachan, R., Prave, A. \& Krabbendam, M., 2010. Fluvial braidplain to shallow marine transition in the early Neoproterozoic Morar Group, Fannich Mountains, northern Scotland. Precambrian Research, 183(4), 791-804.

British Geological Survey, 2004. Ben Wyvis. Scotland Sheet 93W. Bedrock and Superficial Deposits. 1:50 000 Geology Series. Keyworth, Nottingham, British Geological Survey.

British Geological Survey, 2007. Bedrock Geology UK North, 1:625 000 scale. Keyworth, Nottingham, British Geological Survey.

British Geological Survey, 2011. Loch Fannich. Scotland Sheet 92E. Bedrock. 1:50 000 Geology Series. Keyworth, Nottingham: British Geological Survey.

Burns, I.M., 1994. Tectonothermal evolution and petrogensis of the Naver and Kirtomy nappes, north Sutherland, Scotland. Oxford Brookes University.

Butler, R.W.H. 2010. The role of thrust tectonic models in understanding structural evolution in NW Scotland. In: Law, R.D., Butler, R.W.H., Holdsworth, R., Krabbendam, M. \& Strachan, R. (eds) Continental Tectonics and Mountain Building - The Legacy of Peach and Horne. Geological Society, London, Special Publications 335, 293-320.

Cawood, P. A., Strachan, R. A., Merle, R. E., Millar, I. L., Loewy, S. L., Dalziel, I. W., Kinny, P. D., Jourdan, F., Nemchin, A. A. \& Connelly, J. N., 2015. Neoproterozoic to early Paleozoic extensional and compressional history of East Laurentian margin sequences: The Moine Supergroup, Scottish Caledonides. Geological Society of America Bulletin, 127(3-4), 349-371.

Coggon, R., Holland, T., 2002. Mixing properties of phengitic micas and revised garnet-phengite thermobarometers. Journal of Metamorphic Geology 20, 683-696.

Connolly, J.A.D., 1990. Multivariable phase diagrams; an algorithm based on generalized thermodynamics. American Journal of Science 290, 666-718.

Connolly, J.A.D., 2005. Computation of phase equilibria by linear programming: A tool for geodynamic modeling and its application to subduction zone decarbonation. Earth and Planetary Science Letters 236, 524-541.

Coward, M. P., 1985. The thrust structures of southern Assynt, Moine thrust zone. Geological Magazine, 122(6), 595-607.

Cutts, K.A., Hand, M., Kelsey, D.E. \& Strachan, R.A., 2009. Orogenic versus extensional settings for regional metamorphism: Knoydartian events in the Moine Supergroup revisited. Journal of the Geological Society, 166(2), 201-204.

Cutts, K.A., Kinny, P.D.., Strachan, R.A, Hand, M., Kelsey, D.E., Emery, M., Friend, C.R. \& Leslie, A.G, 2010. Three metamorphic events recorded in a single garnet: Integrated phase modelling, in situ LA-ICPMS and SIMS geochronology from the Moine Supergroup, NW Scotland. Journal of Metamorphic Geology, 28(3), 249267.

Daniel, C. G. \& Pyle, J. M., 2006. Monazite-Xenotime thermochronometry and Al2SiO5 reaction textures in the Picuris Range, Northern New Mexico, USA: new evidence for a 1450-1400 Ma orogenic event. Journal of Petrology, 47(1), 97-118.

Ferry, J.t., Spear, F., 1978. Experimental calibration of the partitioning of Fe and $\mathrm{Mg}$ between biotite and garnet. Contributions to Mineralogy and Petrology 66, 113-117. 
Faleiros, F.M., Moraes, R., Pavan, M., \& Campanha, C., 2016. A new empirical calibration of the quartz c-axis opening-angle deformation thermometer. Tectonophysics, 671, 173-182.

Fettes, D., Long, C., Bevins, R., Max, M., Oliver, G., Primmer, T., Thomas, L., Yardley, B., 1985. Grade and time of metamorphism in the Caledonide Orogen of Britain and Ireland, in: Harris, A.L. (Ed.), The Nature, London and timing of orogenic activity in the Caledonian rocks of the British Isles. Memoirs of the Geological Society. Geological Society of London, London, pp. 41-53.

Freeman, S.R., Butler, R.W.H., Cliff, R.A., Rex, D.C., 1998. Direct dating of mylonite evolution: a multidisciplinary geochronological study from the Moine thrust zone, NW Scotland. Journal of the Geological Society London, 155, 745-758.

Friend, C., Jones, K., Burns, I., 2000. New high-pressure granulite event in the Moine Supergroup, northern Scotland: Implications for Taconic (early Caledonian) crustal evolution. Geology 28, 543-546.

Furman, M., Lindsley, D., 1988. Ternary feldspar modeling and thermometry. Am Mineral 73, 201-215.

Giletti, B.J., Moorbath, S., Lambert, R.S.J., 1961. A geochronological study of the metamorphic complexes of the Scottish Highlands. Quarterly Journal of the Geological Society 117, 233-264.

Goodenough, K.M., Millar, I., Strachan, R.A., Krabbendam, M., Evans, J.A., 2011. Timing of regional deformation and development of the Moine Thrust Zone in the Scottish Caledonides: constraints from the U-Pb geochronology of alkaline intrusions. Journal of the Geological Society 168, 99-113.

Grant, C.J., Harris, A.L., 2000. The kinematic and metamorphic history of the Sgurr Beag Thrust, Ross-shire, NW Scotland. Journal of Structural Geology 22, 191-205.

Harker, R.J., 1953. The metamorphic history of the Carn Chuinneag-Inchbae massif and its environment. PhD thesis, Cambridge University.

Harker, R.J., 1954. Further data on the petrology of the politic hornfelses of the Carn Chuinneag-Inchbae region, Ross-shire, with special reference to the status of almandine. Geological Magazine, 91, 445-462.

Heinrich, W., REHS, G. \& Franz, G., 1997. Monazite-xenotime miscibility gap thermometry. I. An empirical calibration. Journal of Metamorphic Geology, 15(1), 3-16.

Holdsworth, R.E., 1989. The geology and structural evolution of a Caledonian fold and ductile thrust zone, Kyle of Tongue region, Sutherland, Northern Scotland. Journal of the Geological Society 146, 809-823.

Holdsworth, R. E., 1990. Progressive deformation structures associated with ductile thrusts in the Moine Nappe, Sutherland, N. Scotland. Journal of Structural Geology, 12(4), 443-452.

Holdsworth, R.E., Strachan, R.A., Harris, A.L., 1994. The Moine Supergroup, in: Gibbons, W., Harris, A.L. (Eds.), A Revised Correlation of Precambrian rocks in the British Isles. Geological Society of London Special Reports, pp. 23-32.

Holland, T., Baker, J., Powell, R., 1998. Mixing properties and activity-composition and relationships of chlorites in the system MgO-FeO-Al 2 O 3-SiO 2-H 2 O. European Journal of Mineralogy 10, 395-406.

Holland, T., Powell, R., 1998. An internally consistent thermodynamic data set for phases of petrological interest. Journal of Metamorphic Geology 16, 309-343.

Hyslop, E.K. 1999. Carn Gorm. In: Mendum, J.R., Barber A.J. Butler, R.W.H., Flinn, D., Goodenough, K.M., Krabbendam, M., Park, R.G., Stewart, A.D. (eds) Lewisian, Torridonian and Moine Rocks of Scotland. Geological Conservation Review Series, Joint Nature Conservation Committee, Peterborough, 451-455.

Johnson, M.R.W, Shepherd, J., 1970. Notes on the age of metamorphism of the Moinian. Scottish Journal of Geology, 6, 228-229.

Johnson, M., Strachan, R., 2006. A discussion of possible heat sources during nappe stacking: the origin of Barrovian metamorphism within the Caledonian thrust sheets of NW Scotland. Journal of the Geological Society 163 , 579-582.

Kelley, S.P., 1988. The relationship between K-Ar mineral ages, mica grain sizes and movement on the Moine thrust zone, NW Highlands, Scotland. Journal of the Geological Society, London, 145, 1-10.

Kelley, S.P. 2009a. Fannich. In: Mendum, J.R., Barber A.J. Butler, R.W.H., Flinn, D., Goodenough, K.M., Krabbendam, M., Park, R.G., Stewart, A.D. (eds) Lewisian, Torridonian and Moine Rocks of Scotland. Geological Conservation Review Series, Joint Nature Conservation Committee, Peterborough, 486-491.

Kelley, S.P. 2009b. Meall an T-Sithe and Creag Rainich. In: Mendum, J.R., Barber A.J. Butler, R.W.H., Flinn, D., Goodenough, K.M., Krabbendam, M., Park, R.G., Stewart, A.D. (eds) Lewisian, Torridonian and Moine Rocks of Scotland. Geological Conservation Review Series, Joint Nature Conservation Committee, Peterborough, 491-494. 
Kelley, S.P., 2010. Excursion 9. Loch a'Bhraoin, Braemore and Loch Broom, p. 162 - 175. In: Strachan, R.A., Alsop, I., Friend, C.R.L., Miller, S., 2010. An Excursion Guide to the Moine Geology of the Northern Highlands of Scotland. Edinburgh Geological Society \& Geological Society of Glasgow, Edinburgh, Scotland.

Kelley, S. \& Powell, D. 1985. Relationships between marginal thrusting and movement on major internal shear zones in the northern Highland Caledonides, Scotland. Journal of Structural Geology, 7, 161-174.

Kinny, P.D., Friend, C.R.L., Strachan, R.A., Watt, G.R., Burns, I.M., 1999. U-Pb geochronology of regional migmatites in East Sutherland, Scotland: evidence for crustal melting during the Caledonian orogeny. Journal of the Geological Society 156, 1143-1152.

Kinny, P.D., Strachan, R.A., Friend, C.R.L., Kocks, H., Rogers, G., Paterson, B.A., 2003a. U-Pb geochronology of deformed metagranites in central Sutherland, Scotland: evidence for widespread late Silurian metamorphism and ductile deformation of the Moine Supergroup during the Caledonian orogeny. Journal of the Geological Society 160, 259-269.

Kinny, P.D., Strachan, R.A., Kocks, H., Friend, C.R.L., 2003b. U-Pb geochronology of late Neoproterozoic augen granites in the Moine Supergroup, NW Scotland: dating of rift-related, felsic magmatism during supercontinent break-up? Journal of the Geological Society 160, 925-934.

Kocks, H., Strachan, R.A., Evans, J.A., 2006. Heterogeneous reworking of Grampian metamorphic complexes during Scandian thrusting in the Scottish Caledonides: insights from the structural setting and $\mathrm{U}-\mathrm{Pb}$ geochronology of the Strath Halladale Granite. Journal of the Geological Society 163, 525-538.

Kohn, M. J., 2016. Metamorphic chronology- a tool for all ages: Past achievements and future prospects. American Mineralogist, 101, 25-42.

Krabbendam, M., Urai, J. L., van Vliet, L. J., 2003. Grain size stabilisation by dispersed graphite in a high-grade quartz mylonite: an example from Naxos (Greece). Journal of structural Geology, 25(6), 855-866.

Krabbendam, M., Prave, T., Cheer, D., 2008. A fluvial origin for the Neoproterozoic Morar Group, NW Scotland; implications for Torridon-Morar Group correlation and the Grenville Orogen foreland basin. Journal of the Geological Society 165, 379-394.

Krabbendam, M., Strachan, R.A., Leslie, A.G., Goodenough, K.M., Bonsor, H.C., 2011. The internal structure of the Moine Nappe Complex and the stratigraphy of the Morar Group in the Fannichs-Beinn Dearg area, NW Highlands. Scottish Journal of Geology 47, 1-20.

Krabbendam, M., Bonsor, H., Horstwood, M. S., \& Rivers, T. 2017. Tracking the evolution of the Grenvillian foreland basin: Constraints from sedimentology and detrital zircon and rutile in the Sleat and Torridon groups, Scotland. Precambrian Research, 295, 67-89.

Krabbendam, M., Ramsay, J.G., Leslie, A.G., Tanner, P.W.G., Goodenough, K.M., 2018. Caledonian and Knoydartian overprinting of a Grenvillian inlier and the enclosing Morar Group rocks: structural evolution of the Precambrian Proto-Moine Nappe, Glenelg, NW Scotland. Scottish Journal of Geology 54.

Kruhl, J. H., 1996. Prism-and basal-plane parallel subgrain boundaries in quartz: A microstructural geothermobarometer. Journal of Metamorphic Geology, 14(5), 581-589.

Kruhl, J.H., 1998. Reply: Prism- and basal-plane parallel subgrain boundaries in quartz: a microstructural geothermobarometer. Journal of Metamorphic Geology 16, 142-146.

Kylander-Clark, A. R., Hacker, B. R. \& Cottle, J. M., 2013. Laser-ablation split-stream ICP petrochronology. Chemical Geology, 345, 99-112.

Lancaster, P.J., Strachan, R.A., Bullen, D., Fowler, M., Jaramillo, M., Saldarriaga, A.M., 2017. U-Pb zircon geochronology and geodynamic significance of 'Newer Granite' plutons in Shetland, northernmost Scottish Caledonides. Journal of the Geological Society, London, 174, 486-497.

Law, R. D., 2014. Deformation thermometry based on quartz c-axis fabrics and recrystallization microstructures: A review. Journal of Structural Geology, 66, 129-161.

Law, R.D., Johnson, M., 2010. Microstructures and crystal fabrics of the Moine thrust zone and Moine nappe: history of research and changing tectonic interpretations. Geological Society, London, Special Publications 335, 443-503.

Law, R.D., Searle, M.P., Simpson, R.L., 2004. Strain, deformation temperatures and vorticity of flow at the top of the Greater Himalayan Slab, Everest Massif, Tibet. Journal of the Geological Society of London 161, 305-320. 
Law, R.D., Mazza, S.E., Thigpen, R. Mako, C., Ashley, K., Krabbendam, M. 2017. Shear senses and deformation temperatures indicated by quartz C-axis fabrics and microstructures in a NW-SE transect across the Moine and Sgurr Beag thrust sheets of northern Scotland. 21st International Conference on Deformation, Rheology and Tectonics. Inverness, Scotland. 30 April - 4 May 2017.

Leslie, A. G., Krabbendam, M., Kimbell, G. S., \& Strachan, R. A. 2010. Regional-scale lateral variation and linkage in ductile thrust architecture: the Oykel Transverse Zone, and mullions, in the Moine Nappe, NW Scotland. Geological Society, London, Special Publications, 335(1), 359-381.

Lister, G.S., Hobbs, B.E., 1980. The simulation of fabric development during plastic deformation and its application to quartzite; the influence of deformation history. Journal of Structural Geology 2, 355-370.

Long, L.E., Lambert, R.S.J., 1963. Rb-Sr isotopic ages from the Moine Series, in: Johnson, M.R.W., Stewart, F.H. (Eds.), The British Caledonides, pp. 217-247.

Mahar, E.M., Baker, J., Powell, R., Holland, T., Howell, N., 1997. The effect of Mn on mineral stability in metapelites. Journal of Metamorphic Geology 15, 223-238.

Mendum, J., Barber, A., Butler, R., Flinn, D., Goodenough, K.M., Krabbendam, M., Park, R., Stewart, A., 2009. Lewisian, Torridonian and Moine Rocks of Scotland. Joint Nature Conservation Committee.

Moorhouse, S.J., Moorhouse, V.E., 1988. The Moine assemblage in Sutherland, in: Winchester, J.A. (Ed.), Later Proterozoic Stratigraphy of the Northern Atlantic Regions. Blackie and Sons, Glasgow, pp. 54-73.

Morgan, S.S., Law, R.D., 2004. Unusual transition in quartzite dislocation creep regimes and crystal slip systems in the aureole of the EJB pluton, California: a case for anhydrous conditions created by decarbonation reactions. Tectonophysics 384, 209-231.

Olgaard, D. L. \& Evans, B., 1986. Effect of second-phase particles on grain growth in calcite. Journal of the American Ceramic Society, 69(11).

Oliver, G.J.H., Wilde, S.A., Wan, Y., 2008. Geochronology and geodynamics of Scottish granitoids from the late Neoproterozoic break-up of Rodinia to Paleozoic collision. Journal of the Geological Society of London 165, 661-674.

Park, R. G., 2005. The Lewisian terrane model: a review. Scottish Journal of Geology, 41(2), 105-118.

Paton, C., Hellstrom, J., Paul, B., Woodhead, J. \& Hergt, J., 2011. Iolite: Freeware for the visualisation and processing of mass spectrometric data. Journal of Analytical Atomic Spectrometry, 26(12), 2508-2518.

Peach, B.N., Horne, J., Gunn, W., Clough, C.T., Hinxman, L.W., Teall, J.J.H., 1907. The Geological Structure of the North-West Highlands of Scotland. British Geological Survey Memoir.

Peach, B., Gunn, W., Clough, C.T., Hinxman,, L.W., Crampton, C.B., Anderson, E.M., Flett, J.S., 1912. The Geology of Ben Wyvis, Carn Chuinneag, Inchbae and surrounding country. British Geological Survey Memoir.

Pidgeon, R. \& Johnson, M., 1974. A comparison of zircon U-Pb and whole-rock Rb-Sr systems in three phases of the Carn Chuinneag granite, northern Scotland. Earth and Planetary Science Letters, 24(1), 105-112.

Pidgeon, R. \& Compston, W., 1992. A SHRIMP ion microprobe study of inherited and magmatic zircons from four Scottish Caledonian granites. Transactions of the Royal Society of Edinburgh: Earth Sciences, 83(1-2), 473-483.

Powell, D., Holland, T., 1994. Optimal geothermometry and geobarometry. American Mineralogist 79, 120-133.

Powell, R., Holland, T., 1999. Relating formulations of the thermodynamics of mineral solid solutions: activity modeling of pyroxenes, amphiboles, and micas. American Mineralogist 84, 1-14.

Powell, D., Phillips, W., 1985. Time of deformation in the Caledonide Orogen of Britain and Ireland. Geological Society, London, Memoirs 9, 17-39.

Pyle, J. M., Spear, F. S., Rudnick, R. L. \& McDonough, W. F., 2001. Monazite-xenotime-garnet equilibrium in metapelites and a new monazite-garnet thermometer. Journal of Petrology, 42(11), 2083-2107.

Rathbone, P.A., Harris, A.L., 1979. Basement-cover relationships at Lewisian inliers in the Moine rocks. Geological Society, London, Special Publications 8, 101-107.

Read, H., 1931. The Geology of Central Sutherland (Sheets 108 and 109). British Geological Survey Memoir, 238.

Rogers, G., Hyslop, E., Strachan, R., Paterson, B. \& Holdsworth, R., 1998. The structural setting and U-Pb geochronology of Knoydartian pegmatites in W Inverness-shire: evidence for Neoproterozoic tectonothermal events in the Moine of NW Scotland. Journal of the Geological Society, 155(4), 685-696. 
Rogers, G., Kinny, P., Strachan, R., Friend, C. \& Paterson, B., 2001. U-Pb geochronology of the Fort Augustus granite gneiss: constraints on the timing of Neoproterozoic and Palaeozoic tectonothermal events in the NW Highlands of Scotland. Journal of the Geological Society, 158(1), 7-14.

Shepherd, J. 1973. The structure and structural dating of the Carn Chuinneag intrusion, Ross-shire. Scottish Journal of Geology, 9, 63-88.

Soper, N., Brown, P., 1971. Relationship between metamorphism and migmatization in the northern part of the Moine Nappe. Scottish Journal of Geology, 7, 305-325.

Stipp, M., Stunitz, H., Heilbronner, 2002. The Eastern Tonale Fault Zone: a 'natural laboratory' for crystal plastic deformation of quartz over a temperature range from 250 to $700{ }^{\circ} \mathrm{C}$. Journal of Structural Geology 24., 1861-1884.

Strachan, R.A., Holdsworth, R.E., 1988. Basement cover relationships and structure within the Moine rocks of central and southeast Sutherland. Journal of the Geological Society 145, 23-36.

Strachan, R.A., Smith, M., Harris, A.L. \& Fettes, D.J. 2002. The Northern Highland and Grampian terranes. In: Trewin, N. (ed.) Geology of Scotland (4th edition). Geological Society, London, 87-147.

Strachan, R., Evans, J., 2008. Structural setting and U-Pb zircon geochronology of the Glen Scaddle Metagabbro: evidence for polyphase Scandian ductile deformation in the Caledonides of northern Scotland. Geological Magazine 145, 361.

Strachan, R. A., Holdsworth, R. E., Krabbendam, M., \& Alsop, G. I. 2010a. The Moine Supergroup of NW Scotland: insights into the analysis of polyorogenic supracrustal sequences. Geological Society, London, Special Publications, 335(1), 233-254.

Strachan, R.A., Holdsworth, B., Krabbendam, M., Leslie, G., Soper, J. 2010b. Excursion 10: South and Central Sutherland, pp 184 - 190. In: Strachan, R.A., Alsop, I., Friend, C.R.L., Miller, S., 2010. An Excursion Guide to the Moine Geology of the Northern Highlands of Scotland. Edinburgh Geological Society \& Geological Society of Glasgow, Edinburgh, Scotland.

Stewart, A.D., 2002, The later Proterozoic Torridonian rocks of Scotland: their sedimentology, geochemistry and origin. Geological Society of London.

Tanner, P.W.G., 1970. The Sgurr Beag Slide-a major tectonic break within the Moinian of the Western Highlands of Scotland. Quarterly Journal of the Geological Society 126, 435-463.

Tanner, P.W.G., Evans, J.A., 2003. Late Precambrian U-Pb titanite age for peak regional metamorphism and deformation (Knoydartian orogeny) in the western Moine, Scotland. Journal of the Geological Society 160, 555-564.

Thigpen, J.R., Law, R.D., Lloyd, G.E., Brown, S.J., Cook, B., 2010. Deformation temperatures, vorticity of flow and strain symmetry in the Loch Eriboll mylonites, NW Scotland: implications for the kinematic and structural evolution of the northernmost Moine Thrust zone. Geological Society, London, Special Publications 335, 623-662.

Thigpen, J.R., Law, R.D., Loehn, C., Strachan, R.A., Tracy, R., Lloyd, G., Roth, B., Brown, S., 2013. Thermal structure and tectonic evolution of the Scandian orogenic wedge, Scottish Caledonides: Integrating geothermometry, deformation temperatures, and kinematic-thermal modeling. Journal of Metamorphic Geology, 31, 813-842.

Tilley, C.E., 1935. The role of kyanite in the 'hornfels' zone of the Carn Chuinneag granite, Ross-shire. Mineralogical Magazine, 24, 92-97.

Tomkins, H. \& Pattison, D., 2007. Accessory phase petrogenesis in relation to major phase assemblages in pelites from the Nelson contact aureole, southern British Columbia. Journal of Metamorphic Geology, 25, 401-421.

Tullis, J., Christie, J.M., Griggs, D.T., 1973. Microstructures and Preferred Orientations of Experimentally Deformed Quartzites. Geological Society of America Bulletin 84, 297-314.

Vance, D., Strachan, R., Jones, K., 1998. Extensional versus compressional settings for metamorphism: Garnet chronometry and pressure-temperature-time histories in the Moine Supergroup, northwest Scotland. Geology 26, 927-930.

Walker, S., Thirlwell, M.F., Strachan, R.A., Bird, A.F. 2016. Evidence from Rb-Sr mineral ages for multiple orogenic events in the caledonides of Shetland, Scotland. Journal of the Geological Society, London, 173, 489-503.

Wilson, D., 1975. Structure and metamorphism of the Ben Wyvis District, Ross-shire. University of Edinburgh. 
Wilson, D., Shepherd, J., 1979. The Carn Chuinneag granite and its aureole. Geological Society, London, Special Publications 8, 669-675.

Winchester, J.A., 1974. The zonal pattern of regional metamorphism in the Scottish Caledonides. Journal of the Geological Society 130, 509-524.

White, R., Pomroy, N., Powell, R., 2005. An in situ metatexite-diatexite transition in upper amphibolite facies rocks from Broken Hill, Australia. Journal of Metamorphic Geology 23, 579-602.

Zeh, A. \& Millar, I., 2001. Metamorphic evolution of garnet-epidote-biotite gneiss from the Moine Supergroup, Scotland, and geotectonic implications. Journal of Petrology, 42(3), 529-554. 
Figures.

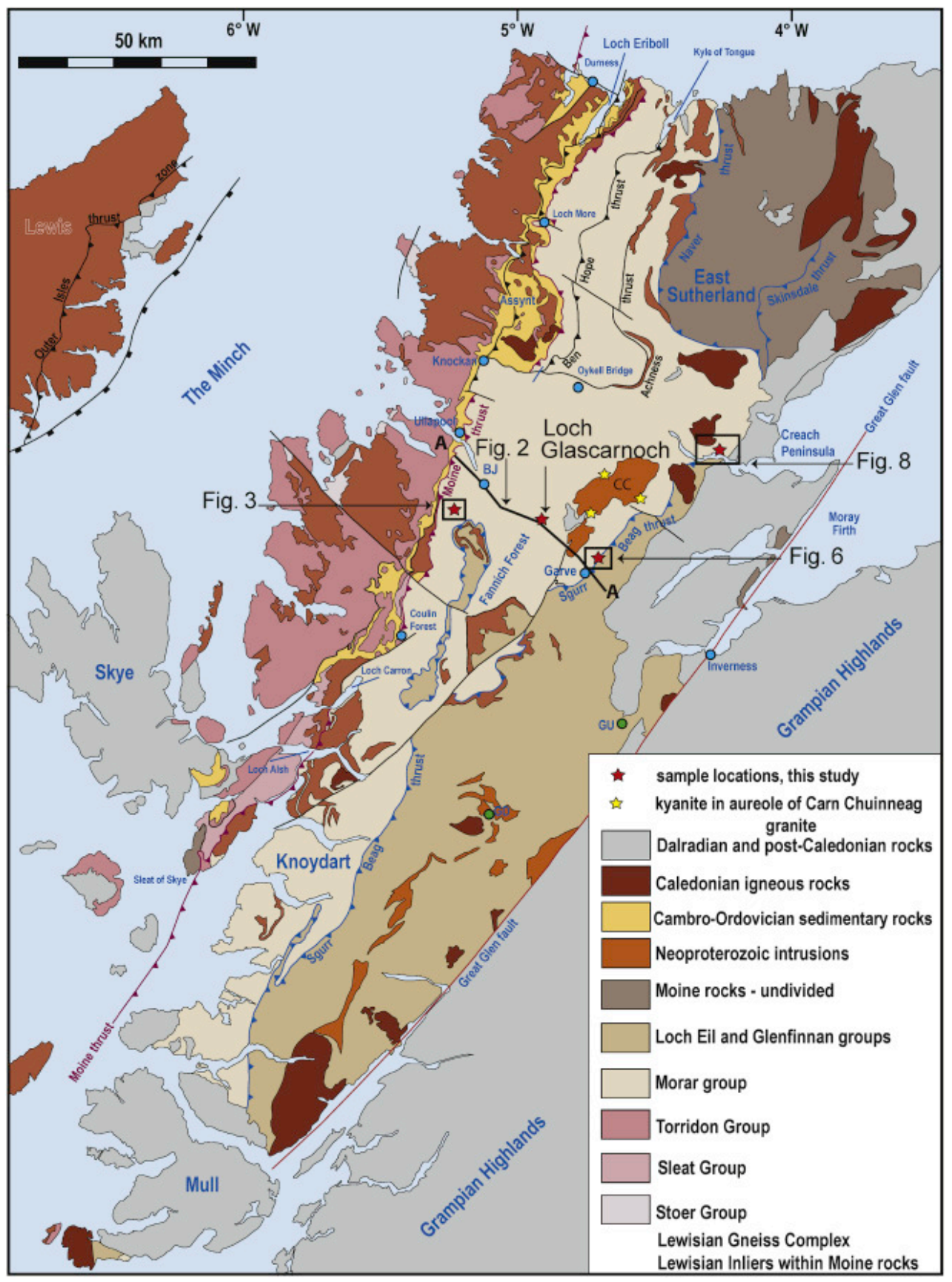

Fig. 1. Regional scale geologic map of northern Scotland, showing major rock units and tectonic features. Locations of study areas are highlighted. Cross section from Braemore Junction (BJ) to Rogie Falls (Fig. 2) is indicated by line $A-A^{\prime}$, crossing through the Moine and Sgurr Beag thrust sheets. Stars represent locations for new P-T calculations. Adapted from British Geological Survey (2007); Krabbendam et al. (2008); Thigpen et al. (2010). Locations of other areas discussed in text: CC - Carn Chuinneag granite; GD - Glen Doe; GU - Glen Urquhart. 


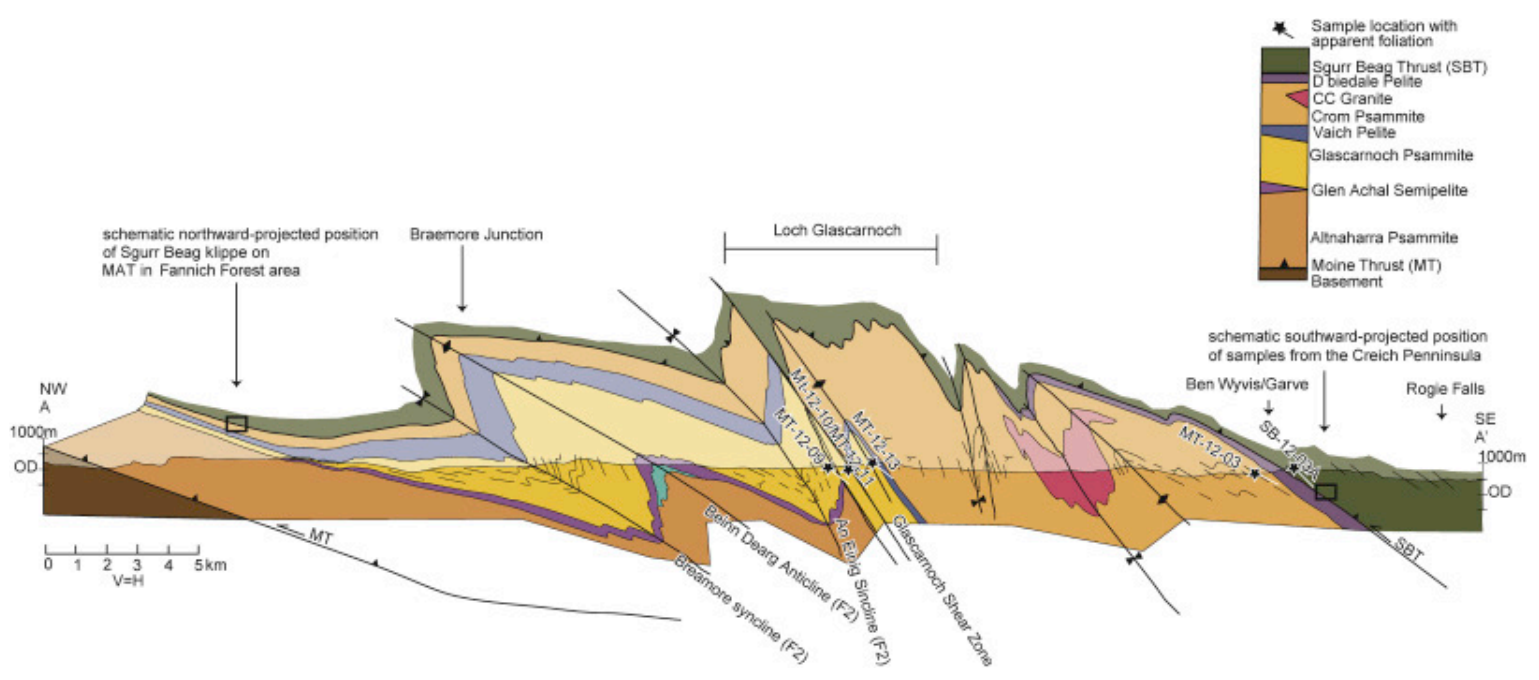

Fig. 2. Regional cross section illustrating geologic structures in the Moine thrust sheet and overlying Sgurr Beag thrust sheet between Moine thrust (MT), Braemore junction and Rogie Falls. Line of section indicated in Fig. 1. Location of samples collected adjacent to the A835 road in the Loch Glascarnoch and Ben Wyvis/Garve areas are projected on to cross section. Northward projected position of the Meall an $t$-Sithe (MAT) sampling area also indicated on cross section; note that in this area the Sgurr Beag thrust (SBT) is only at $400 \mathrm{~m}$ structurally above the Moine thrust (cf. Fig. 3). 
A)

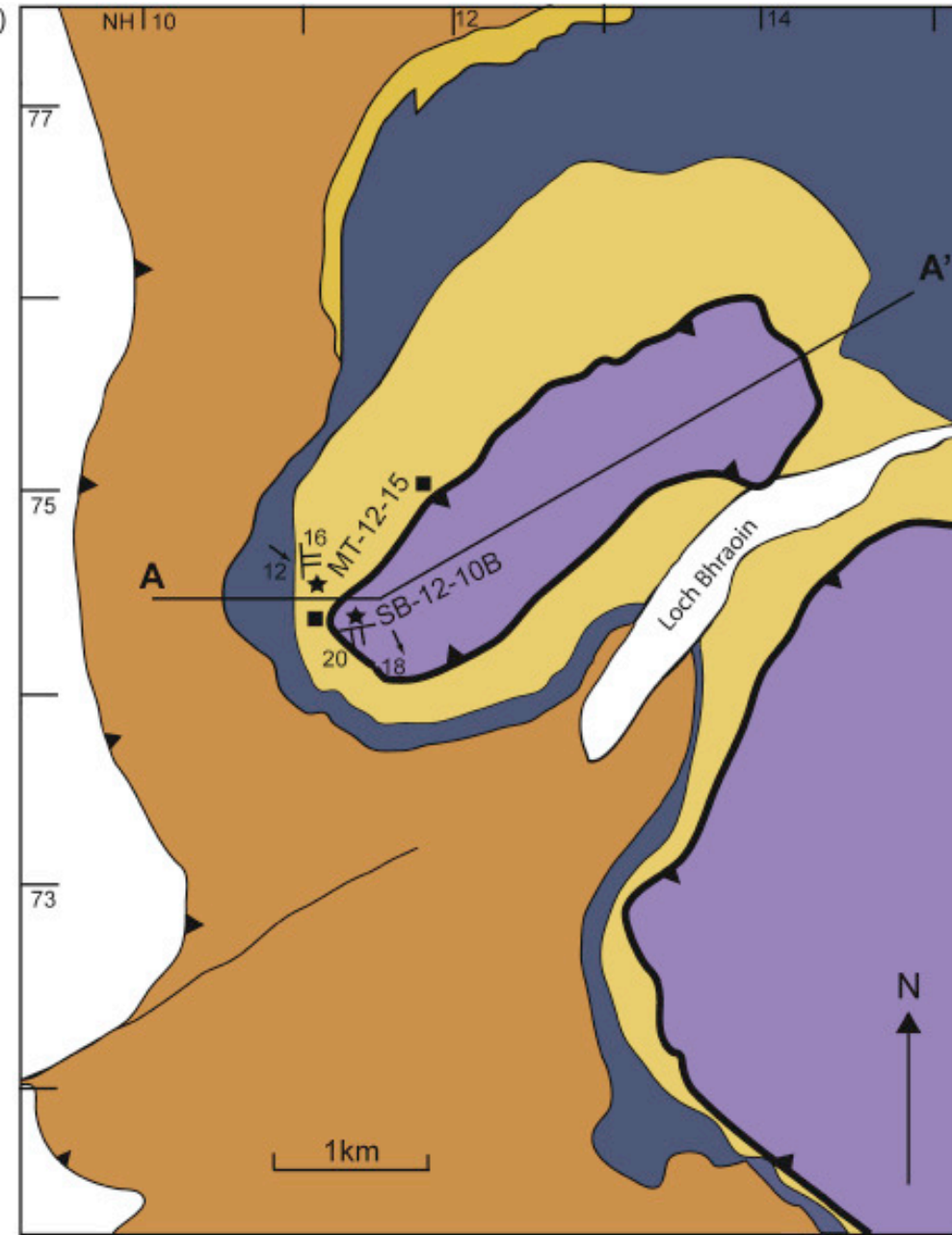

Glenfinnan Pelite Sgurr BeagThrust Morar Psammite

Vaich Psammite Vaich Pelite

Glascarnoch Psammite Glascarnoch Semipelite Altnaharra Psammite Moine Thrust

Basement

$T_{20}$ foliation

$t_{16}$ lineation

- sample location, this study

- Ar-Ar sample location, Kelley, 1988

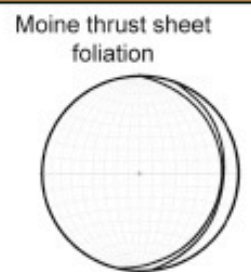

Moine thrust sheet lineation

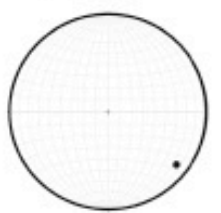

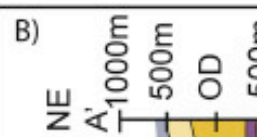

1

1

so

$N^{-12}$

Sgurr Beag thrust sheet

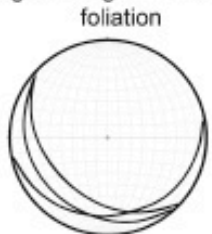

Sgurr Beag thrust sheet lineation

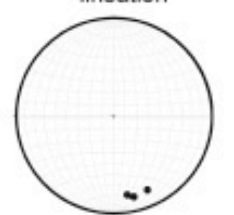

Fig. 3. (a) Geologic map of the northwestern part of Fannich Forest area; adapted from Kelley and Powell (1985), Kelley (2009a, 2009b, 2010), Krabbendam et al. (2011) and British Geological Survey (2011). Locations of samples described in this study, and line of cross section (A-A') in Fig. 3b, indicated. Stereograms of regional foliation and lineations are shown. (b) Cross section through the Sgurr Beag klippe exposed on Meall an t-Sithe (MAT), illustrating structures in the underlying Moine thrust sheet. See also Krabbendam et al. (2011). Location of samples used in this study, and British national grid coordinates (at $1 \mathrm{~km}$ spacing) indicated. 


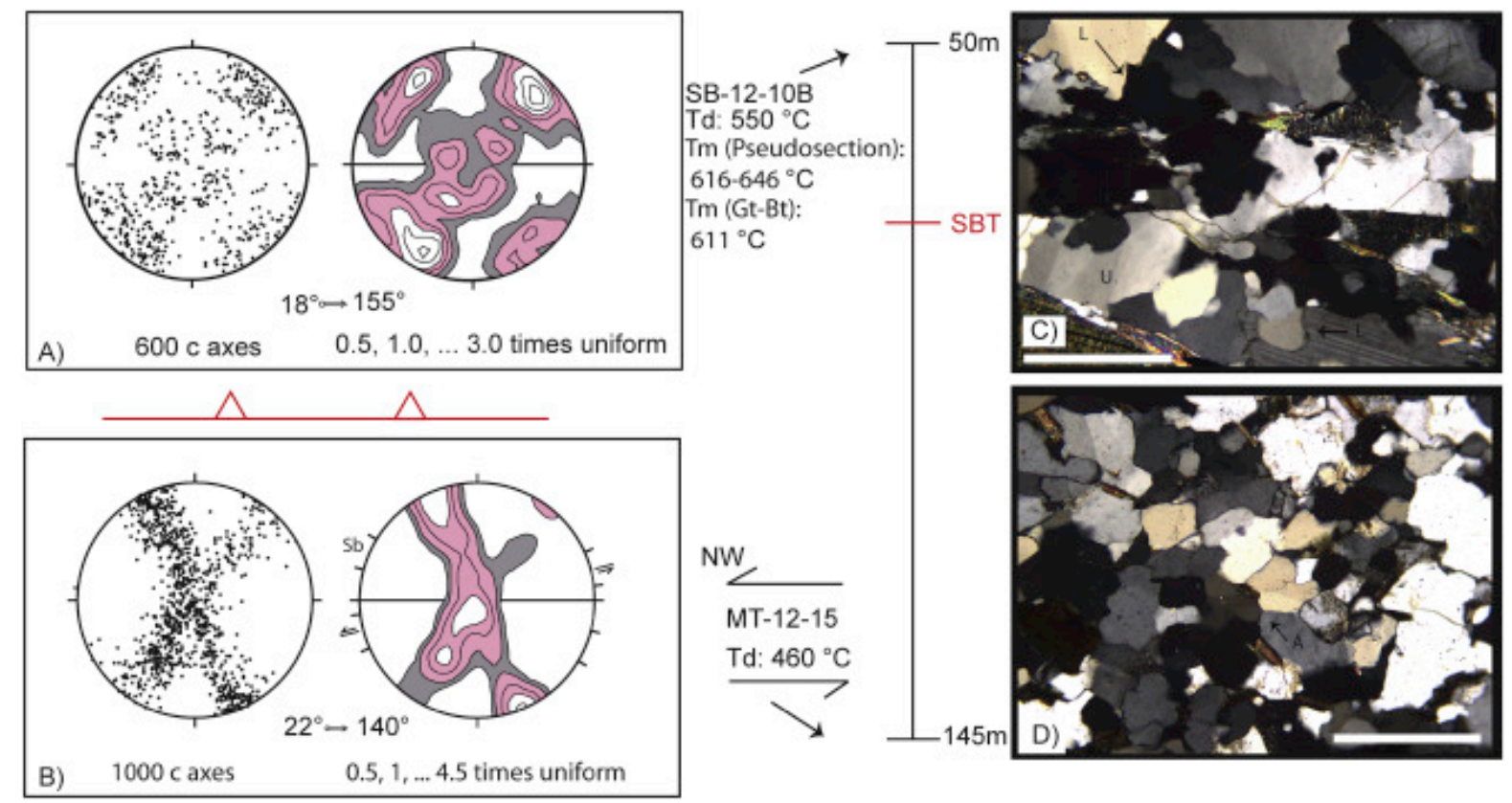

Fig. 4. Quartz c-axis fabrics and microstructures from samples in Moine thrust sheet and overlying Sgurr Beag klippe exposed on Meall an $t$-Sithe in the Fannich Forest area $(a, b)$ Optically measured quartz c-axis fabrics for (a) pelite (SB-12-1OB) from the Sgurr Beag klippe, and (b) psammite (MT-12-15) in Moine thrust sheet. Lower hemisphere equal area projections orientated perpendicular to foliation and parallel to lineation. Plunge and trend of lineation, orientation of shear bands and long axes of elongate recrystallization grains (Sb) indicated. (c) Photomicrograph of sample SB-12-10B showing lobate quartz grain boundaries (L) and undulose extinction (U) (d) Photomicrograph of sample MT-12-15 showing lobate quartz-quartz grain boundaries and potential annealing microstructure $\left(120^{\circ}\right.$ grain boundaries, A). Scale bars $500 \mu \mathrm{m}$ in length. Asymmetric c-axis fabric and microstructures in samples MT-12-15 indicate a top-to-the-north shear sense. The quartz fabric for sample SB$12-10 B$ is too diffuse to determine shear sense. Deformation temperatures (Td) estimated from fabric opening angles and temperatures of metamorphism (Tm) estimated by pseudosection and garnet-biotite (Gt-Bt) thermometry in individual samples are shown. 

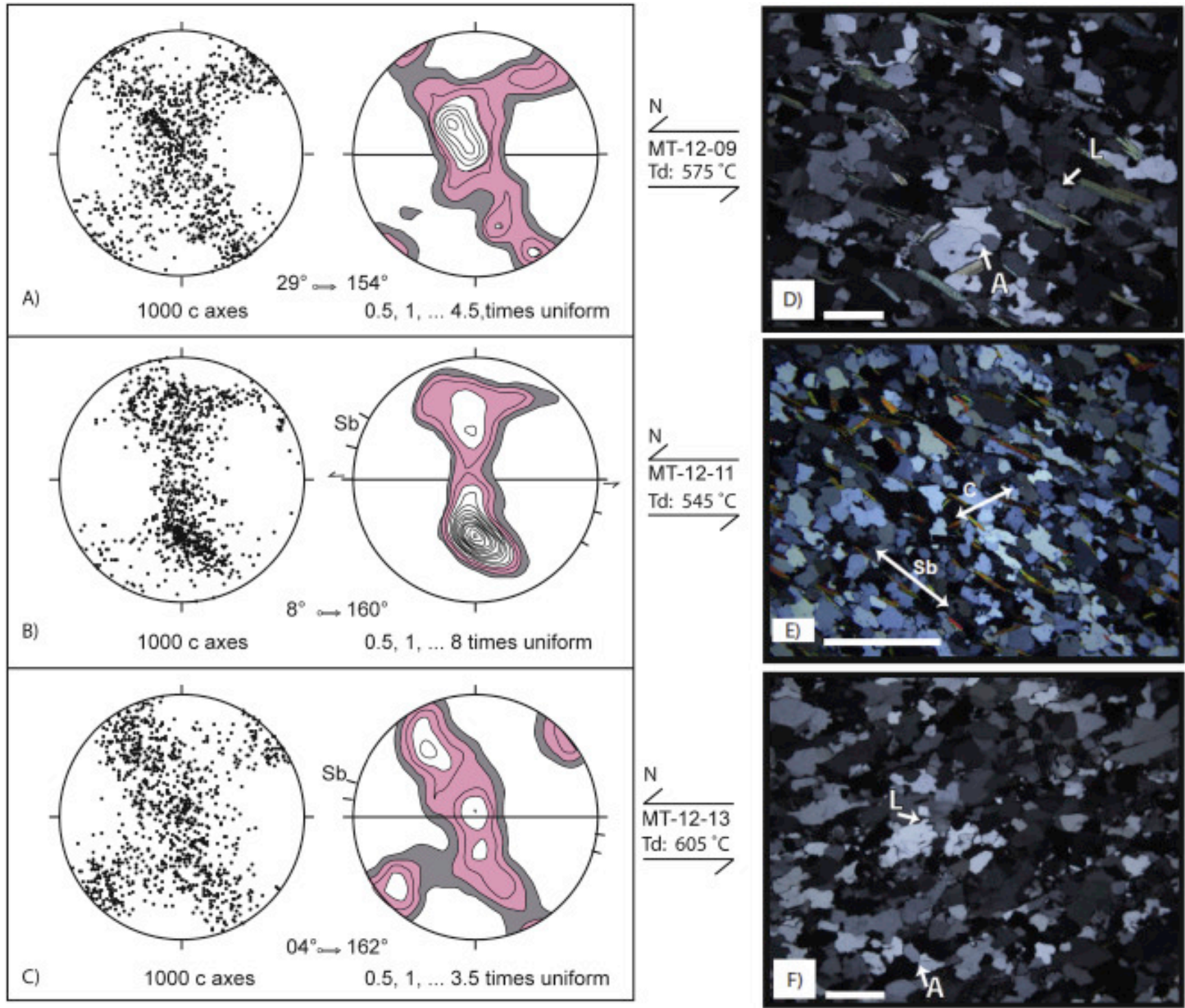

Fig. 5. Optically measured quartz c-axis fabrics and microstructures from the central part of the Moine thrust sheet, collected along the north shore of Loch Glascarnoch (Fig. 1, Fig. 2). Plunge and trend of lineation and orientation of long axes of elongate recrystallized grains (Sb) indicated. (a) Psammite (MT-12-09), (b) pelite (MT-12-11) and, (c) psammite (MT-12-13) with asymmetric fabrics indicating a top to the north shear sense. (d) sample MT-12-09 has a single foliation defined by mica grains while (e) sample MT-12-11 is an S-C mylonite defined by mica foliation surfaces with $S b$ and C surfaces corresponding to $S b$ and the arrows in the quartz caxis fabric, respectively (this figure b) and (f) sample MT-12-13 with lobate grain boundaries (L), $120^{\circ}$ grain boundaries $(A)$ and local subgrains. Scale bar is $1 \mathrm{~mm}$ in length. 

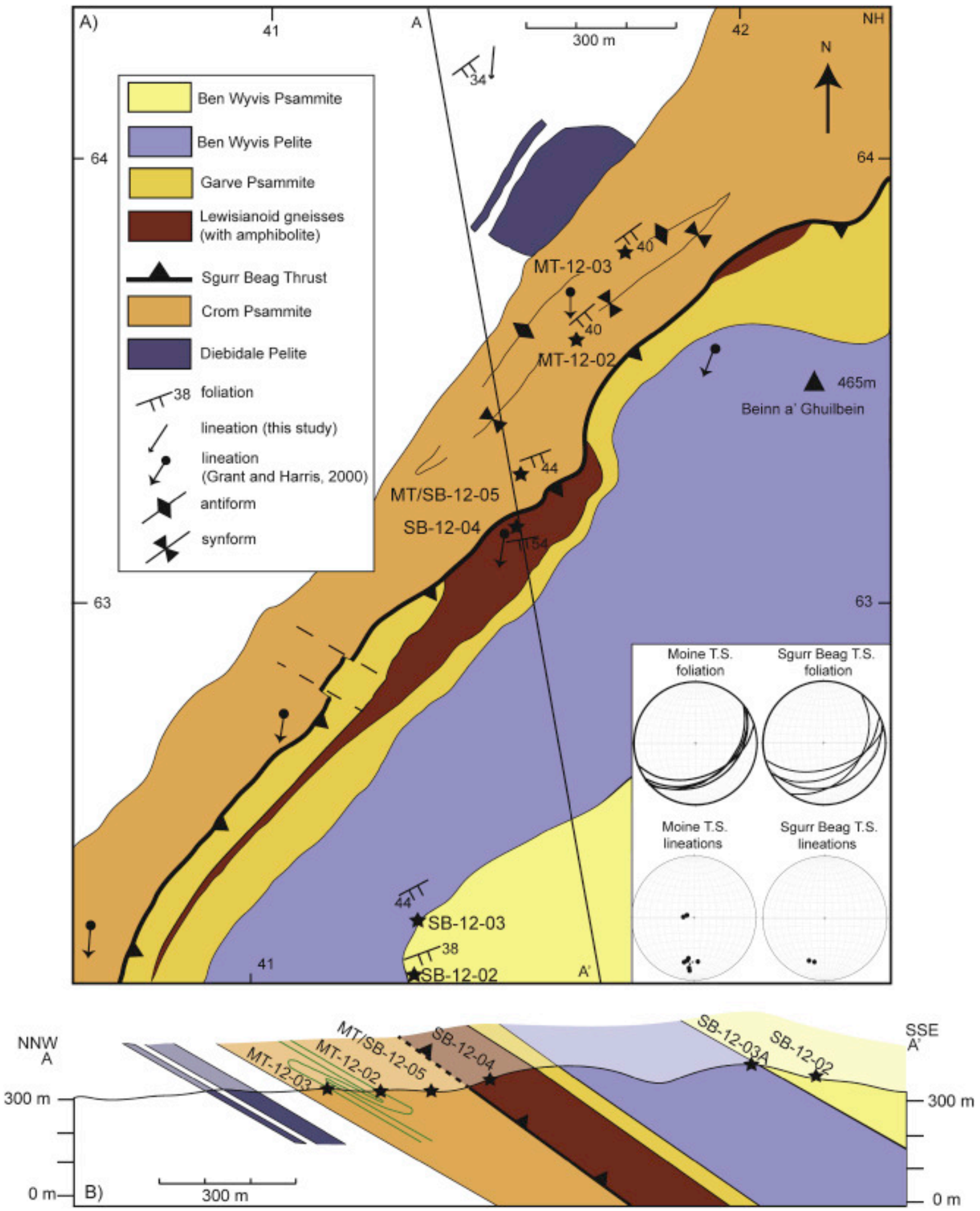

Fig. 6. (a) Geologic map of the Sgurr Beag thrust zone between Garve and Ben Wyvis; modified from Grant and Harris (2000) and British Geological Survey (2004). Sample locations and British national grid coordinates (at $1 \mathrm{~km}$ spacing) indicated. A-A' indicates the line of section for Fig. 6b. (b) Geologic cross section along line A-A' highlighting the Morar Group in the footwall and the Glenfinnan Group in the hanging wall to the Sgurr Beag thrust. 
A)
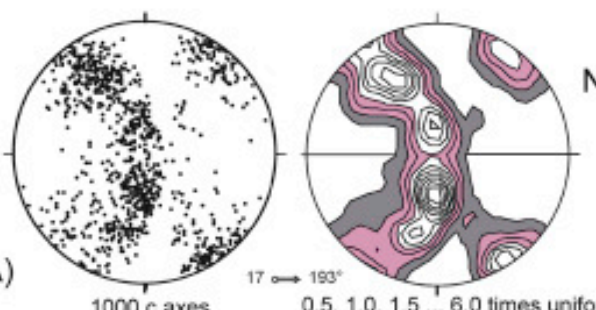

SB-12-03A

Tm (Pseudosection):

Tm (Gt-Bt Thermometry) $589^{\circ} \mathrm{C}$

B)
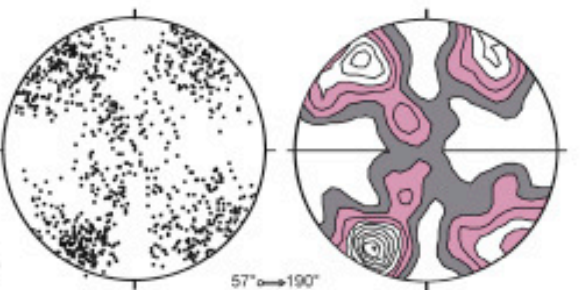

$0.5,1.0,1.5 \ldots 5.5$ times uniform
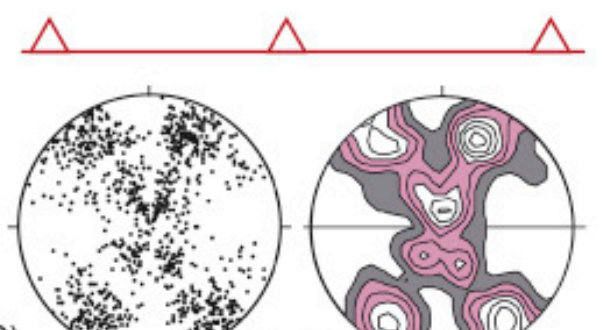

C)

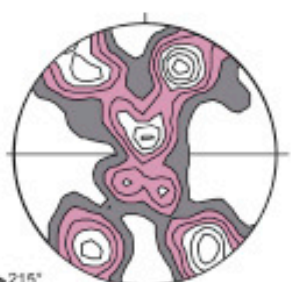

$0.5,1.0,1.5, .40$ times uniform

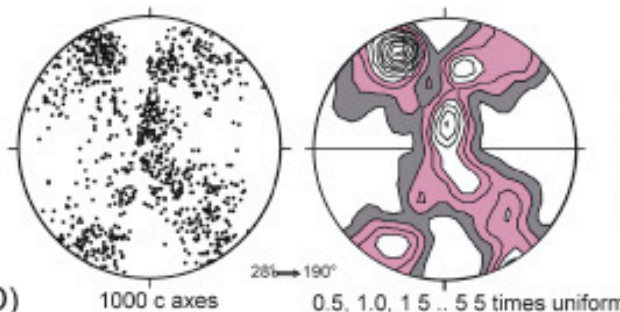

D)
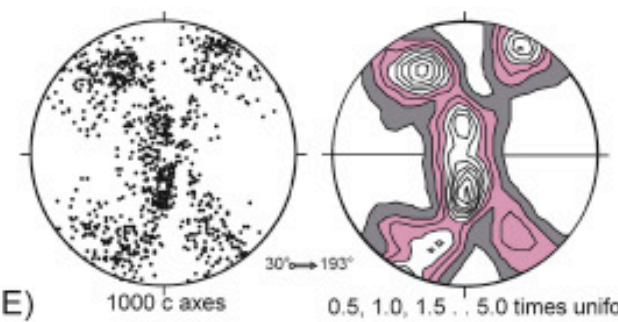

$0.5,1.0,1.5,5.0$ times uniform
$\mathrm{N} \sum_{\text {SB-12-02 }}$ $583^{\circ} \mathrm{C}$
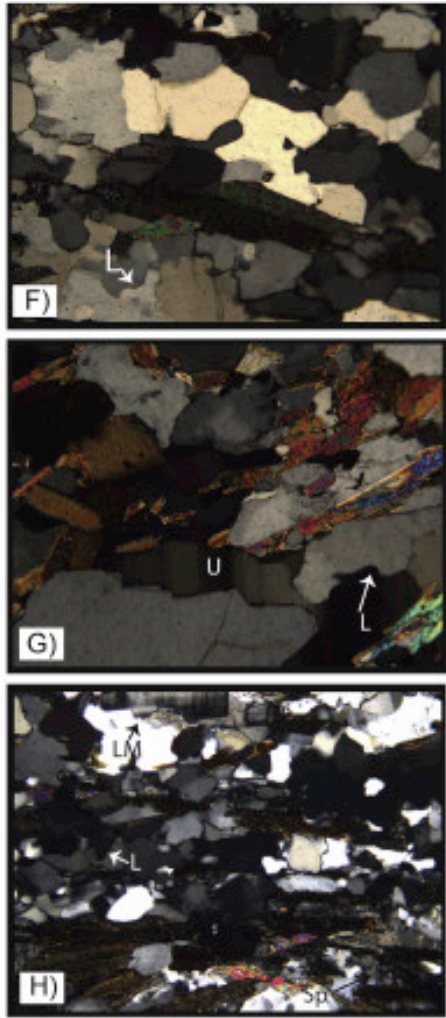

SBT

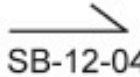

$545^{\circ} \mathrm{C}$
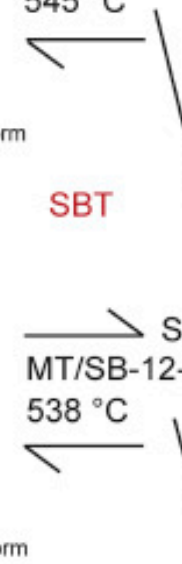

$\mathrm{S}$

-05
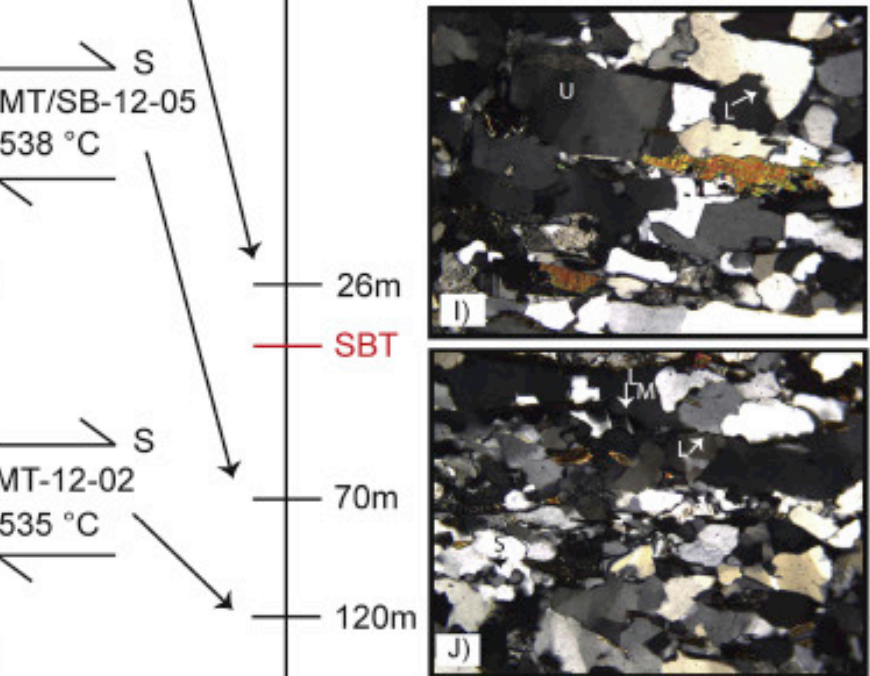

$120 \mathrm{~m}$

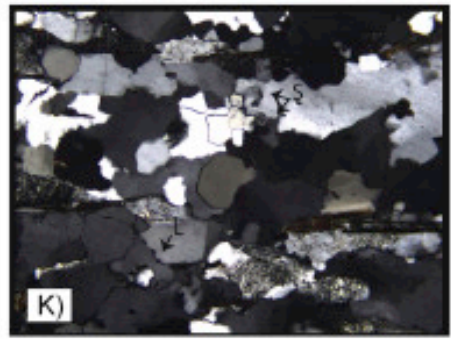

Fig. 7. Optically measured quart c-axis fabrics and microstructures associated with samples from the Ben Wyvis/Garve area (see Fig. 6 for locations). (a) psammite (SB-12-02) and (b) psammite (SB-12-04) from Sgurr Beag thrust sheet and (c) psammite (MT/SB-12-05), (d) psammite (MT-12-02), and (e) psammite (MT-12-03) from the Moine thrust sheet; asymmetric fabrics for MT-12-04, MT-12-03, MT-12-02, SB-12-05 suggest top-tothe-south transport. Deformation temperatures $(T d)$ estimated from fabric opening angles and temperatures of metamorphism (Tm) estimated by garnet-biotite thermometry and from pseudosection analysis (sample SB-12- 
03A) are indicated. Lower hemisphere equal area projections orientated perpendicular to foliation and parallel to lineation, plunge and trend of lineation indicated. (f) SB-12-02 with lobate quartz grain boundaries (g) SB-1203 with lobate quartz grain boundaries (L) and undulose extinction in quartz grains (U); and (h) SB-12-04 with lobate grain boundaries in both quartz (L) and microcline (LM), as well as subgrains in quartz (S) and plagioclase (Sp); (i) MT(SB)-12-05 with lobate quartz grain boundaries (L) and undulose extinction in quartz grains (U); (j) MT-12-02 with lobate grain boundaries in both quartz (L) and microcline (LM), as well as subgrains in quartz (S); (k) MT-12-03 with lobate quartz grain boundaries (L), and subgrains (S).

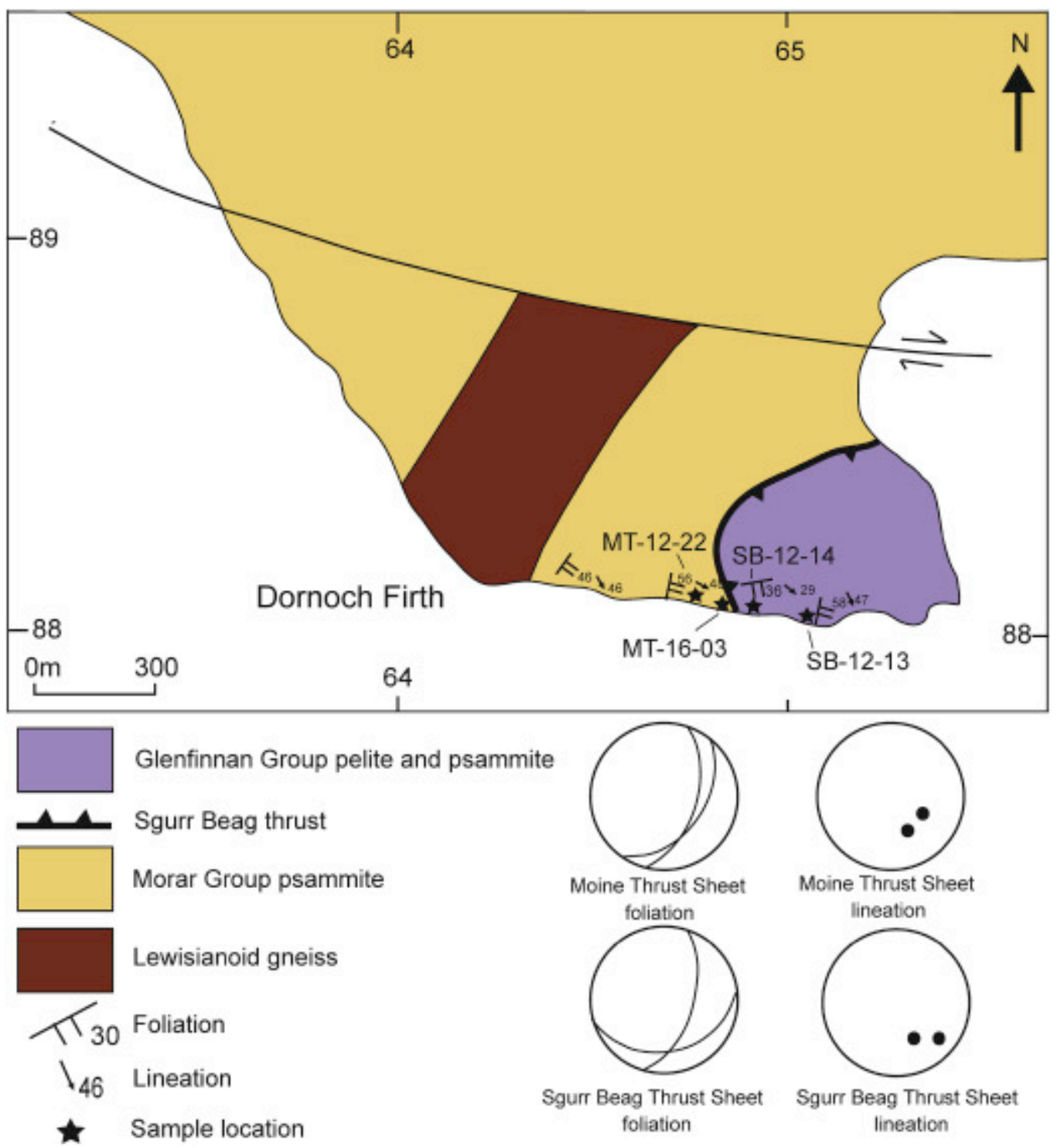

Fig. 8. Geologic map of the Moine and Sgurr Beag thrust sheets exposed on the Creich Peninsula; adapted from Grant and Harris (2000) and Strachan et al. (2010b). Sample locations and British national grid coordinates (at $1 \mathrm{~km}$ spacing) indicated. 


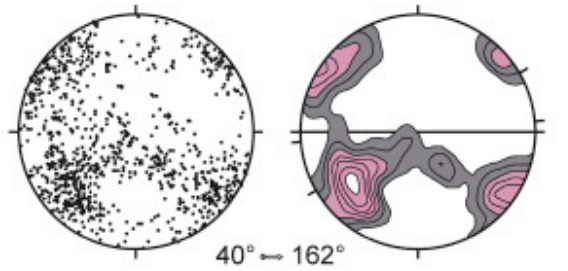

a)

$1000 \mathrm{c}$ axes

$0.5,1, \ldots .4$ times uniform
SB-12-14

Tm (Pseudosection)

Tm (Thermocalc):

Tm (Gt-Bt Thermometry):
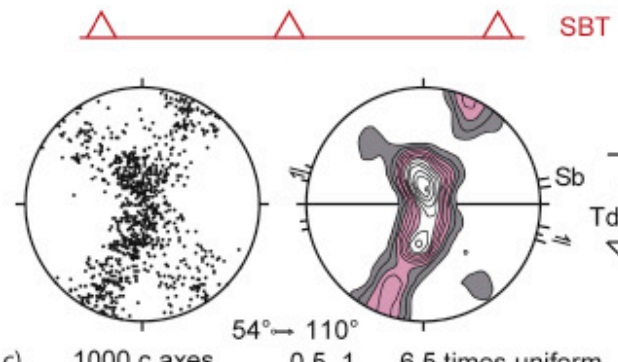

c) $\quad 1000 \mathrm{c}$ axes

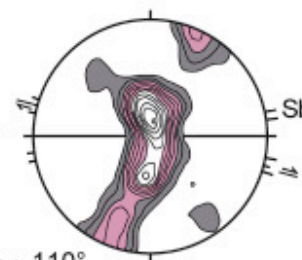

$4^{\circ} \rightarrow 110^{\circ}$ $600-617^{\circ} \mathrm{C}$ $609^{\circ} \mathrm{C}$

$662 \pm 50^{\circ} \mathrm{C}$
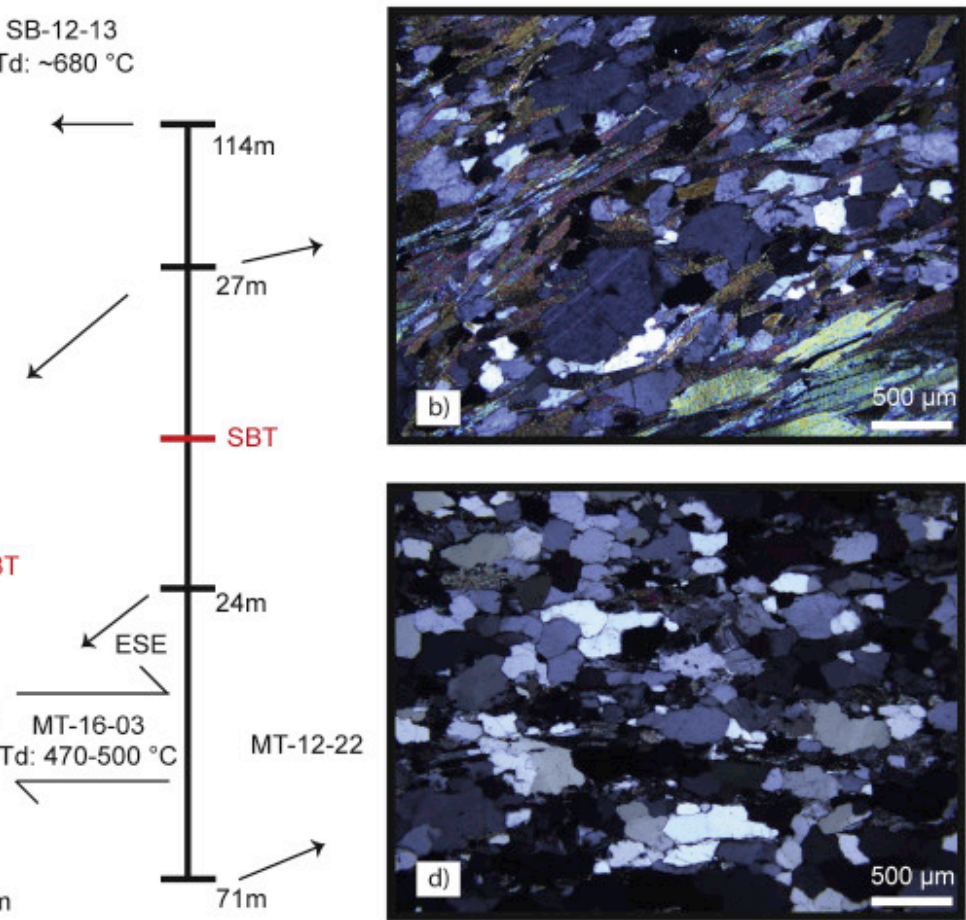

Fig. 9. Microstructures and quartz c-axis fabrics for samples from the Creich Peninsula. (a) psammite (SB-1213). (b) pelite (SB-12-14) from the Sgurr Beag thrust sheet with lobate grain boundaries in both quartz and feldspar. (c) psammite (MT-16-03) from the Moine thrust sheet with dynamically recrystallized quartz and an asymmetric quartz c-axis fabric with top-to-the-ESE shear sense, confirmed by shear bands (arrowed) and elongate recrystallized quartz grains (Sb) oblique to foliation. (d) psammite (MT-12-22). Lower hemisphere equal area projections oriented perpendicular to foliation and parallel to lineation. 

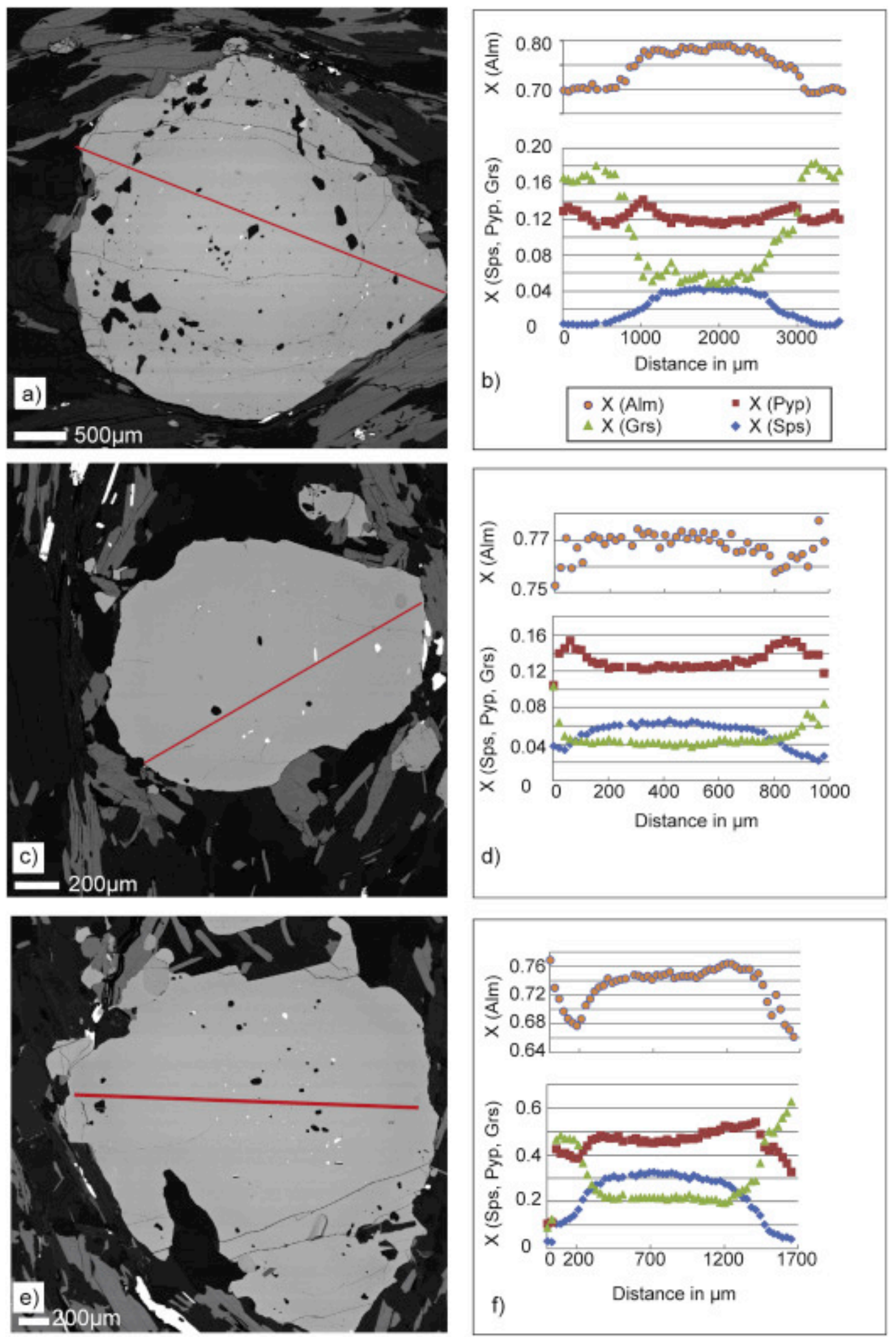

Fig. 10. Backscatter electron images of garnet grains from the Sgurr Beag thrust sheet. (a) SB-12-10B (MAT/Fannich Forest area), (c) SB-12-14 (Creich Peninsula), (e) SB-12-03A (Ben Wyvis/Garve area). Corresponding microprobe chemical transects to map end-members almandine (Alm), spessartine (Sps), pyrope (Pyp), and grossular (Grs) for (b) SB-12-10B, (d) SB-12-14, (f) SB-12-03A. 

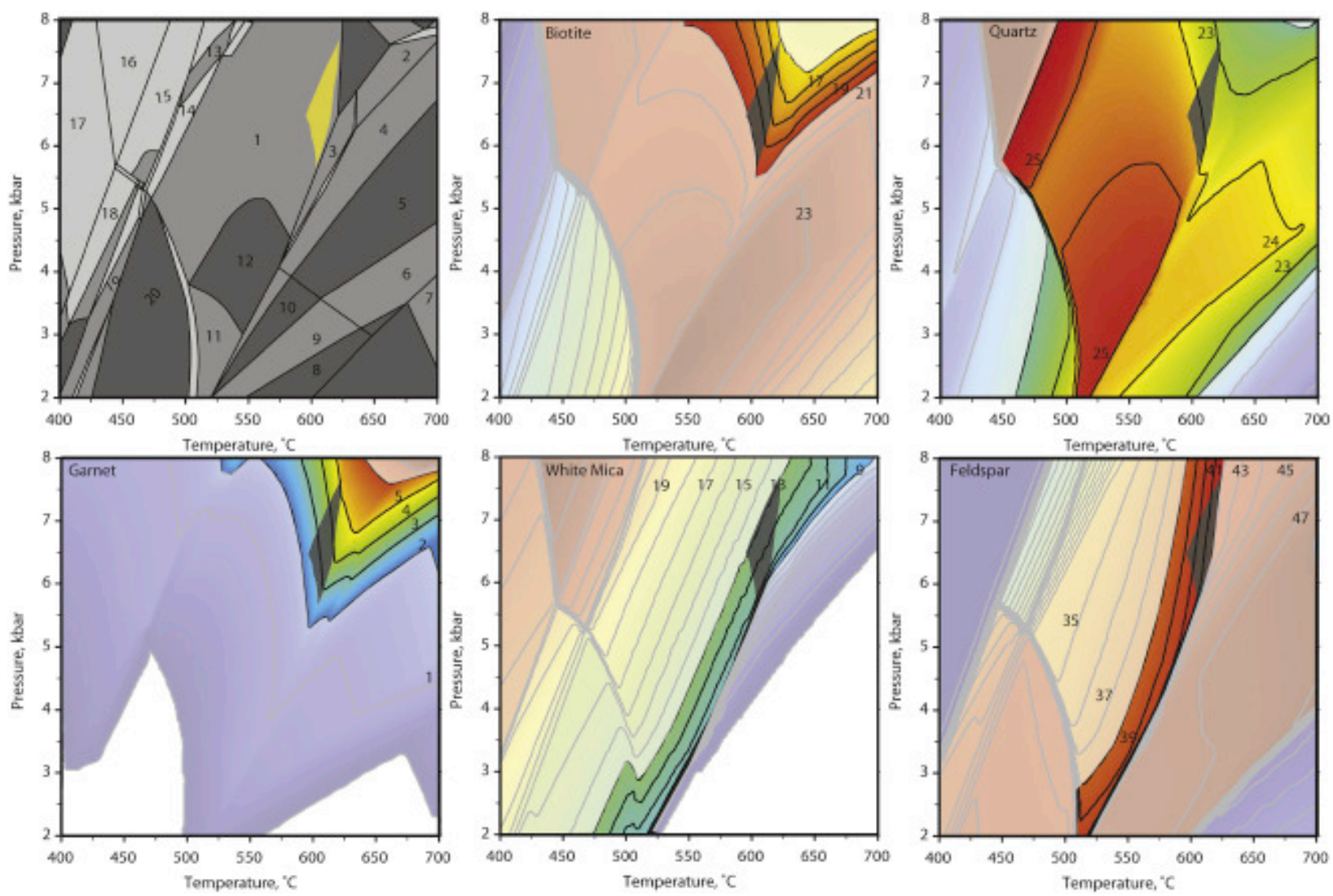

Fig. 11. NaCaMnKFMASHTO pseudosection for sample SB-12-03A from the Ben Wyvis/Garve area. Number fields correspond to the following mineral assemblages: (1) fs (feldspar), wm (white mica), wm, ilm (ilmenite), bt (biotite), gt (garnet), q (quartz) (2) (2) fs, wm, ilm, bt, gt, ky (kyanite), q (3) st (staurolite), fs, wm, ilm, bt, gt, $q(4) f s, w m$, ilm, bt, gt, sil (sillimanite), $q(5) f s, i l m, b t, g t$, sil, $q(6) c r d$ (cordierite), fs, ilm, bt, gt, sil, $q$ (7) crd, fs, $f s, i l m, b t, g t, q(8) \mathrm{crd}, f s, i l m, b t$, and (andalusite), $q$ (9) crd, fs, ilm, bt, gt, and, q (10) fs, ilm, bt, gt, and, q (11) chl (chlorite), fs, wm, ilm, bt, gt, $q$ (12) fs, wm, ilm, bt, gt, $q$ (13) fs, wm, wm, ilm, bt, gt, zo (zoisite), q, ru (rutile) (14) fs, wm, wm, ilm, bt, gt, zo, $q$ (15) fs, wm, wm, bt, gt, zo, sph (sphene), q (16) wm, wm, bt, gt, zo, sph, ab (albite), $q$ (17) chl, wm, bt, gt, zo, sph, ab, q (18) chl, fs, wm, bt, gt, zo, sph, q (19) chl, fs, wm, ilm, bt, sph, $q$ (20) $\mathrm{chl}, \mathrm{fs}, \mathrm{wm}$, ilm, bt, q. Modeled mineral volumes for biotite, quartz, garnet, white mica, and feldspar. Color gradient represent different phase volumes at respective $P$ and $T$ conditions, with black lines representing phase volume. Grey shaded region represents the approximate phase volume found in thin section. Yellow field represents $P$-T space where all modeled phase volumes match what is observed in thin section. (For interpretation of the references to color in this figure legend, the reader is referred to the Web version of this article.) 

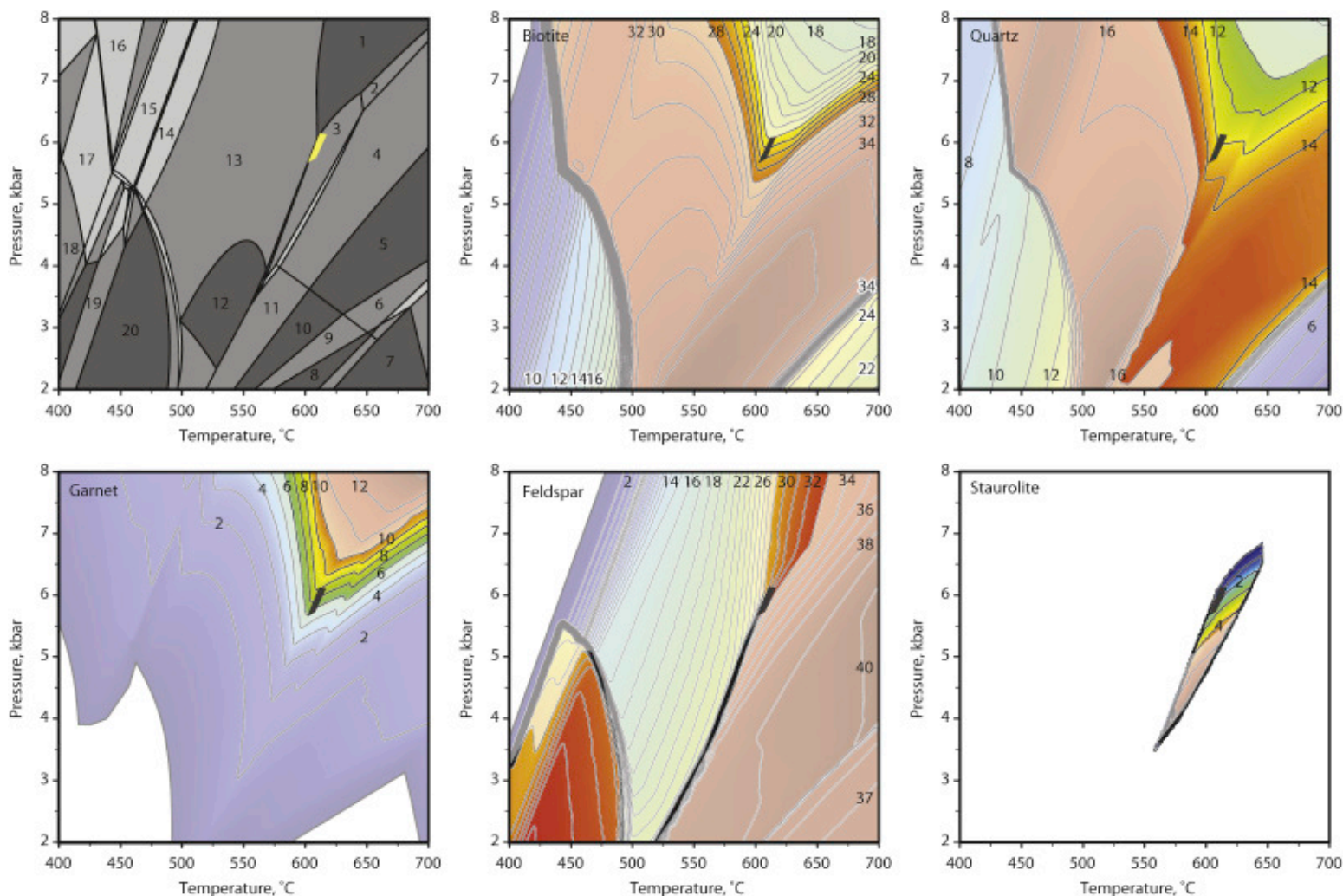

Fig. 12. NaCaMnKFMASHTO pseudosection for sample SB-12-14 from the Creich Peninsula. Field numbers, color gradient, and shaded regions as in Fig. 11 except (11) fs, wm, ilm, bt, gt, and, q (13) fs, wm, wm, ilm, bt, gt, $q$ (16) chl (chlorite), wm, wm, bt, gt, zo, sph, q (18) chl, wm, bt, zo, sph, ab, q. Modeled mineral volumes for biotite, quartz, garnet, feldspar, and staurolite. (For interpretation of the references to color in this figure legend, the reader is referred to the Web version of this article.) 


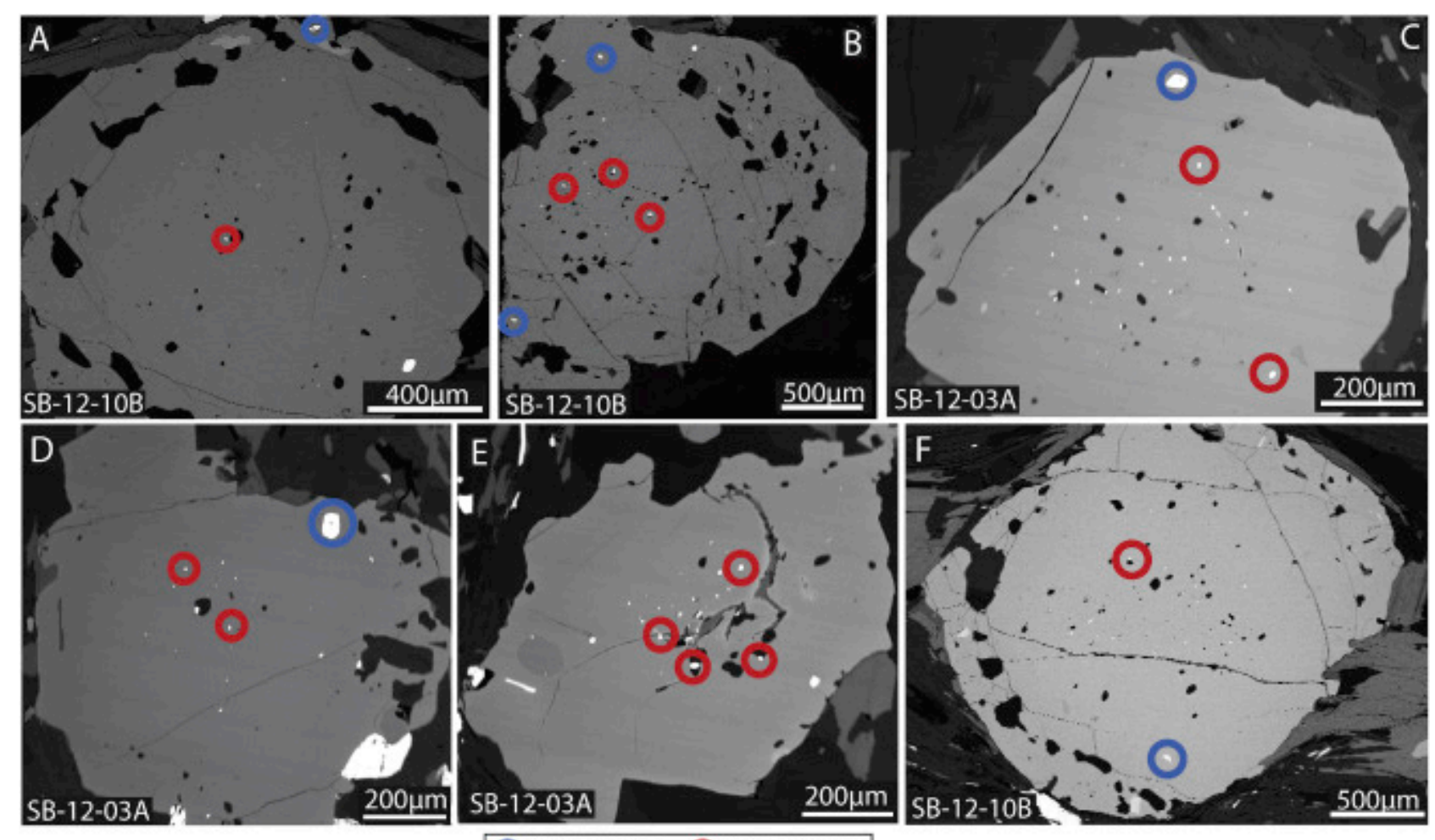

OMonazite OXenotime

Fig. 13. Backscatter electron images showing textural relationships between garnet, xenotime and monazite in samples SB-12-10B and SB-12-03A from the MAT/Fannich Forest and Ben Wyvis/Garve areas, respectively. Monazite is consistently found in garnet rims and xenotime is consistently found in garnet cores, suggesting that crystallization ages of these accessory phases brackets the timing of garnet growth. 

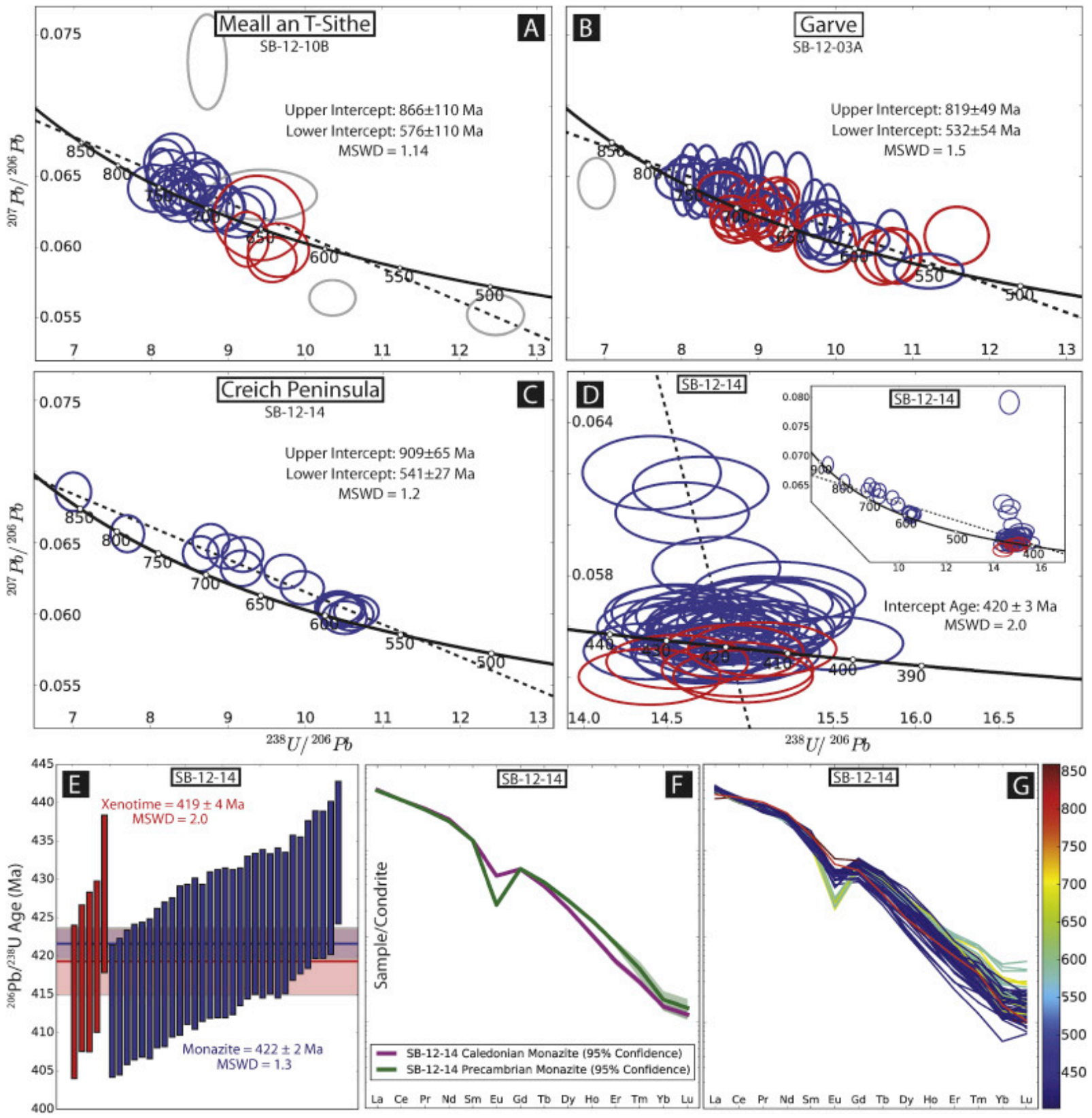

Fig. 14. Summary of monazite and xenotime geochronology. Error ellipses are shown at $2 \sigma$ uncertainty. Xenotime and monazite analyses are shown in red and blue, respectively. Grey ellipses are monazite analyses that were not included in calculations; $a$-d) Tera-Wasserburg diagrams with intercept ages calculated in Isoplot (Ludwig, 2008); e) Weighted averages of concordant monazite and xenotime dates (vertical bars). The mean and $2 \sigma$ uncertainty are shown as horizontal lines and bars with the same color scheme as above; f) Average REE concentrations of monazite for Scandian and Precambrian age populations in SB-12-14. Note the substantial Eu anomaly in Precambrian population relative to the Scandian population; g) REE profiles for each monazite analysis colored by age. Sample locations include: SB-12-10B - MAT/Fannich Forest area; SB-12-03A - Ben Wyvis-Garve area; SB-12-14 - Creich Peninsula. (For interpretation of the references to color in this figure legend, the reader is referred to the Web version of this article.) 


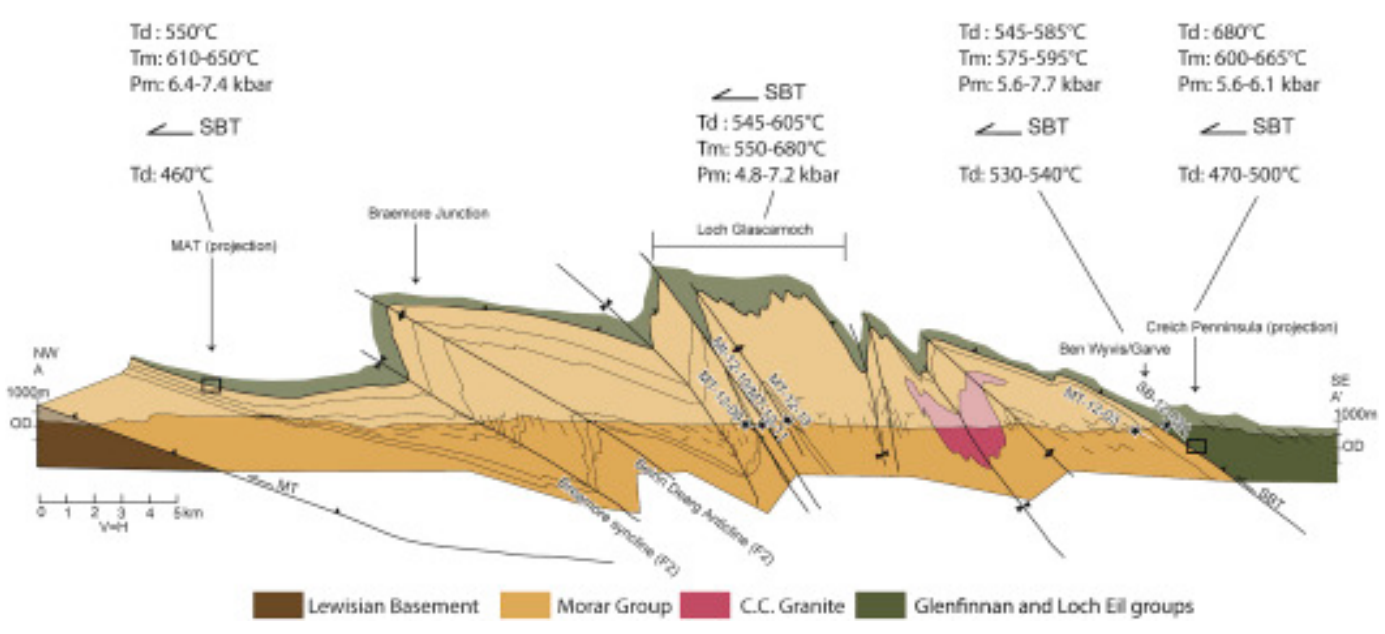

Fig. 15. Simplified version of Fig. 2, with projected summary of Td, Tm, and Pm either for the Morar Group (below the SBT) and Glennfinnan/Loch Eil groups (above the SBT). C.C. - Carn Cuinneag granite; MAT - Meall an T-Sithe klippe; MT-Moine thrust; SBT-Sgurr Beag thrust. 
Tables.

Table 1. Summary of sample locations and types of data collected for individual samples.

\begin{tabular}{|c|c|c|c|c|c|c|c|c|}
\hline \begin{tabular}{|l|} 
Structural \\
position
\end{tabular} & Sample\# & \begin{tabular}{|l} 
Grid \\
reference
\end{tabular} & Photomicrograph & 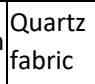 & Petrology & |lsotopic & Data - Figure\# & $\begin{array}{l}\text { Map/cross section } \\
\text { - Fig.\# }\end{array}$ \\
\hline \multicolumn{9}{|c|}{ Meall an t-Sithe - Fannich Forest } \\
\hline $\begin{array}{l}\text { Sgurr Beag thrust } \\
\text { sheet }\end{array}$ & SB-12-10B & $\begin{array}{l}\mathrm{NH} 10410 \\
74710\end{array}$ & $Y$ & Y & $Y$ & Y & $\begin{array}{l}\text { Fig. 4, Fig. 10, Fig. } 13 . \\
\text { Supp. Fig. } 2\end{array}$ & Fig. 3a and b \\
\hline $\begin{array}{l}\text { Moine thrust } \\
\text { sheet }\end{array}$ & MT-12-15 & $\begin{array}{l}\mathrm{NH} 10262 \\
74801\end{array}$ & Y & Y & $* * *$ & $* * *$ & Fig. 4, Fig. 10 & Fig. $3 a$ and $b$ \\
\hline \multicolumn{9}{|l|}{ Loch Glascarnoch } \\
\hline \multirow{4}{*}{$\begin{array}{l}\text { Moine thrust } \\
\text { sheet }\end{array}$} & MT-12-13 & $\begin{array}{l}\text { NH } 32522 \\
72059\end{array}$ & Y & Y & $* * *$ & $* * *$ & Fig. 5 & $* * *$ \\
\hline & MT-12-11 & $\begin{array}{l}\text { NH } 31583 \\
72997\end{array}$ & Y & Y & $* * *$ & $* * *$ & Fig. 5 & $* * *$ \\
\hline & MT-12-10 & $\begin{array}{l}\mathrm{NH} 31583 \\
72997\end{array}$ & $* * *$ & $* * *$ & $Y$ & $* * *$ & Supp. Fig. 1 & $* * *$ \\
\hline & MT-12-09 & $\begin{array}{l}\text { NH } 30869 \\
73742\end{array}$ & $y$ & Y & $* * *$ & $* * *$ & Fig. 5 & $* * *$ \\
\hline \multicolumn{9}{|l|}{ Ben Wyvis/Garve } \\
\hline \multirow{3}{*}{$\begin{array}{l}\text { Sgurr Beag thrust } \\
\text { sheet }\end{array}$} & SB-12-02 & $\begin{array}{l}\mathrm{NH} 41304 \\
62196\end{array}$ & $Y$ & Y & $* * *$ & $* * *$ & Fig. 7 & Fig. 6a and b \\
\hline & SB-12-03A & $\begin{array}{l}\mathrm{NH} 41330 \\
62701\end{array}$ & $* * *$ & $* * *$ & $Y$ & Y & $\begin{array}{l}\text { Fig. 7, Fig. 10, Fig. 11, } \\
\text { Fig. } 13\end{array}$ & Fig. 6a and b \\
\hline & SB-12-04 & $\begin{array}{l}\text { NH } 41523 \\
63176\end{array}$ & $Y$ & Y & $* * *$ & $* * *$ & Fig. 7 & Fig. 6a and b \\
\hline \multirow{3}{*}{$\begin{array}{l}\text { Moine thrust } \\
\text { sheet }\end{array}$} & $\begin{array}{l}\text { MT/SB-12- } \\
05\end{array}$ & $\begin{array}{l}\text { NH } 41551 \\
63295\end{array}$ & Y & $* * *$ & $* * *$ & $* * *$ & Fig. 7 & Fig. 6a and b \\
\hline & MT-12-02 & $\begin{array}{l}\text { NH } 41649 \\
63582\end{array}$ & Y & Y & $* * *$ & $* * *$ & Fig. 7 & Fig. 6a and b \\
\hline & MT-12-03 & $\begin{array}{l}\mathrm{NH} 41768 \\
63760\end{array}$ & Y & $Y$ & $* * *$ & $* * *$ & Fig. 7 & Fig. 6a and b \\
\hline \multicolumn{9}{|l|}{ Creich Peninsula } \\
\hline \multirow{2}{*}{$\begin{array}{l}\text { Sgurr Beag thrust } \\
\text { sheet }\end{array}$} & SB-12-13 & $\begin{array}{l}\text { NH } 65058 \\
88013\end{array}$ & $* * *$ & $Y$ & $* * *$ & $* * *$ & Fig. 9 & Fig. 8 \\
\hline & SB-12-14 & $\begin{array}{l}\text { NH } 64896 \\
88042\end{array}$ & Y & $* * *$ & $Y$ & $Y$ & $\begin{array}{l}\text { Fig. 9, Fig. 10, Fig. 12, } \\
\text { Fig. } 14\end{array}$ & Fig. 8 \\
\hline \multirow{2}{*}{$\begin{array}{l}\text { Moine thrust } \\
\text { sheet }\end{array}$} & MT-16-03 & $\begin{array}{l}\text { NH } 64833 \\
88055\end{array}$ & $* * *$ & $Y$ & $* * *$ & $* * *$ & Fig. 9 & Fig. 8 \\
\hline & MT-12-22 & $\begin{array}{l}\mathrm{NH} 64768 \\
88072\end{array}$ & $Y$ & $* * *$ & $* * *$ & $* * *$ & Fig. 9 & Fig. 8 \\
\hline
\end{tabular}

not included. 
Table 2. Summary of mineral compositions.

\begin{tabular}{|c|c|c|c|c|c|c|c|c|c|c|c|c|}
\hline & \multicolumn{3}{|c|}{ Garnet(Rim) } & \multicolumn{3}{|l|}{ Biotite } & \multicolumn{3}{|c|}{ Muscovite } & \multicolumn{3}{|c|}{ Plagioclase } \\
\hline & \begin{tabular}{|l} 
SB-12- \\
$10 B$
\end{tabular} & $\begin{array}{l}\text { SB-12- } \\
14\end{array}$ & $\begin{array}{l}\text { SB-12- } \\
03 A\end{array}$ & $\begin{array}{l}\text { SB-12- } \\
10 B\end{array}$ & $\begin{array}{l}\text { SB-12- } \\
14\end{array}$ & $\begin{array}{l}\text { SB-12- } \\
03 A\end{array}$ & $\begin{array}{l}\text { SB-12- } \\
10 B\end{array}$ & $\begin{array}{l}\text { SB-12- } \\
14\end{array}$ & $\begin{array}{l}\text { SB-12- } \\
03 A\end{array}$ & $\begin{array}{l}\text { SB-12- } \\
10 B\end{array}$ & $\begin{array}{l}\text { SB-12- } \\
14\end{array}$ & $\begin{array}{l}\text { SB-12- } \\
03 A\end{array}$ \\
\hline \multicolumn{13}{|l|}{$w t \%$} \\
\hline $\mathrm{SiO} 2$ & 37.64 & 37.69 & 37.48 & 36.38 & 36.31 & 35.42 & 46.30 & 45.03 & 45.55 & 63.57 & 60.97 & 62.78 \\
\hline TiO2 & 0.06 & 0.00 & 0.04 & 1.94 & 1.49 & 1.77 & 0.94 & 0.87 & 0.84 & 0.00 & 0.00 & 0.00 \\
\hline $\mathrm{Al} 2 \mathrm{O3}$ & 21.98 & 21.86 & 21.96 & 18.78 & 19.86 & 18.99 & 33.02 & 35.20 & 35.64 & 23.47 & 25.02 & 24.11 \\
\hline Cr2O3 & $3-$ & - & - & 0.03 & 0.04 & 0.05 & 0.01 & 0.02 & 0.04 & 0.00 & 0.00 & 0.00 \\
\hline $\mathrm{MgO}$ & 3.25 & 2.84 & 2.96 & 9.96 & 8.68 & 9.93 & 1.45 & 0.75 & 0.79 & 0.00 & 0.00 & 0.00 \\
\hline $\mathrm{CaO}$ & 6.04 & 3.33 & 5.71 & 0.01 & 0.29 & 0.00 & 0.00 & 0.02 & 0.00 & 4.45 & 6.32 & 5.48 \\
\hline $\mathrm{MnO}$ & 0.11 & 1.46 & 0.96 & 0.04 & 0.05 & 0.01 & 0.02 & 0.02 & 0.03 & 0.00 & 0.00 & 0.00 \\
\hline $\mathrm{FeO}$ & 32.19 & 34.07 & 31.89 & 18.42 & 19.72 & 19.62 & 1.44 & 0.92 & 1.06 & 0.06 & 0.03 & 0.05 \\
\hline K2O & - & - & - & 8.05 & 7.45 & 8.60 & 9.21 & 9.87 & 9.73 & 0.11 & 0.06 & 0.07 \\
\hline $\mathrm{Na2O}$ & - & - & - & - & - & - & - & - & - & 9.11 & 8.46 & 8.66 \\
\hline total & 101.27 & 101.24 & 100.99 & 93.60 & 93.88 & 94.40 & 92.38 & 92.70 & 93.68 & 100.76 & 100.86 & 101.15 \\
\hline \multicolumn{4}{|c|}{ Endmember Concentrations } & & & & & & \multicolumn{4}{|c|}{ Endmember Concentrations } \\
\hline Alm & 0.69 & 0.75 & 0.67 & & & & & & $X(A n)$ & 19.42 & 27.05 & 23.89 \\
\hline Sps & 0.00 & 0.03 & 0.02 & & & & & & $x(A b)$ & 79.62 & 72.43 & 75.49 \\
\hline Pyp & 0.13 & 0.13 & 0.12 & & & & & & & & & \\
\hline Grs & 0.17 & 0.09 & 0.19 & & & & & & & & & \\
\hline
\end{tabular}


Table 3. Summary of whole rock compositions.

\begin{tabular}{|c|c|c|c|c|}
\hline $\mathrm{Wt} \%$ & MT-12-10 & SB-12-03A & SB-12-10B & SB-12-14 \\
\hline $\mathrm{SiO2}$ & 56.50 & 58.64 & 59.03 & 51.43 \\
\hline TiO2 & 0.98 & 1.01 & 1.13 & 1.3 \\
\hline Al2O3 & 20.54 & 19.07 & 19.51 & 23.8 \\
\hline Fe2O3T & 8.08 & 8.34 & 9.9 & 10.84 \\
\hline $\mathrm{MnO}$ & 0.15 & 0.20 & 0.15 & 0.24 \\
\hline $\mathrm{MgO}$ & 2.24 & 2.30 & 2.65 & 2.71 \\
\hline $\mathrm{CaO}$ & 1.25 & 2.76 & 1.57 & 2.37 \\
\hline $\mathrm{Na} 2 \mathrm{O}$ & 2.18 & 3.48 & 1.72 & 2.84 \\
\hline K2O & 4.89 & 2.69 & 4 & 4.14 \\
\hline P2O5 & 0.17 & 0.20 & 0.27 & 0.45 \\
\hline $\mathrm{SO} 3$ & - & - & 0.06 & 0.05 \\
\hline Total & 100.05 & 99.93 & 99.99 & 100.17 \\
\hline LOI & 3.71 & 1.97 & 3.71 & 3.06 \\
\hline $\mathrm{FeO}$ & 1.67 & 1.02 & 5.9 & 8.2 \\
\hline \multirow[t]{2}{*}{$\mathrm{Fe} 2 \mathrm{O} 3$} & 5.77 & 6.59 & 3.34 & 1.73 \\
\hline & \multicolumn{4}{|c|}{ Approximate mineral abundances } \\
\hline Qtz & 26 & 24 & 30 & 13 \\
\hline $\mathrm{Bt}$ & 20 & 18 & 22 & 26 \\
\hline$W m$ & 28 & 11 & 22 & 20 \\
\hline Felds & 28 & 40 & 18 & 31 \\
\hline Gt & 1 & 4 & 8 & 8 \\
\hline St & - & - & - & 2 \\
\hline \multicolumn{5}{|l|}{ ppm } \\
\hline Sr & 217 & 320 & 184 & 274 \\
\hline $\mathrm{Zr}$ & 186 & 213 & 224 & 247 \\
\hline V & 147 & 127 & 150 & 157 \\
\hline $\mathrm{Cr}$ & 121 & 107 & 128 & 123 \\
\hline
\end{tabular}


Table 4. Summary of temperatures and pressures of metamorphism $(\mathrm{Tm}, P)$ and deformation temperature $(T d)$ when available.

\begin{tabular}{|c|c|c|c|c|c|c|c|}
\hline $\begin{array}{l}\text { Structural } \\
\text { position }\end{array}$ & Sample\# & \begin{tabular}{|l|} 
Quartz \\
Fabric (Td)
\end{tabular} & $\begin{array}{l}\text { Pseudosection } \\
(\mathrm{Tm})\end{array}$ & $\begin{array}{l}\text { Pseudosection } \\
\text { (P) }\end{array}$ & $\begin{array}{l}\text { Garnet-Biotite, } \\
\text { Ferry and Spear } \\
(\mathrm{Tm})\end{array}$ & $\begin{array}{l}\text { THERMOCALC } \\
(\mathrm{Tm})\end{array}$ & $\begin{array}{l}\text { THERMOCALC } \\
\text { (P) }\end{array}$ \\
\hline \multicolumn{8}{|c|}{ Meall an t-Sithe - Fannich Forest } \\
\hline \begin{tabular}{|l} 
Sgurr Beag \\
thrust sheet
\end{tabular} & SB-12-10B & 550 & $615-645$ & $6.4-7.4$ & $610 \pm 50$ & 565 & $6.4 \pm 1.4$ \\
\hline $\begin{array}{l}\text { Moine thrust } \\
\text { sheet }\end{array}$ & MT-12-15 & 460 & & & & & \\
\hline \multicolumn{8}{|c|}{ Loch Glascarnoch } \\
\hline \multirow[t]{4}{*}{$\begin{array}{l}\text { Moine thrust } \\
\text { sheet }\end{array}$} & MT-12-13 & 605 & & & & & \\
\hline & MT-12-11 & 545 & & & & & \\
\hline & MT-12-10 & & $550-680$ & $2.8-7.2$ & & & \\
\hline & MT-12-09 & 575 & & & & & \\
\hline \multicolumn{8}{|c|}{ Ben Wyvis/Garve } \\
\hline \multirow[t]{3}{*}{\begin{tabular}{|l|} 
Sgurr Beag \\
thrust sheet
\end{tabular}} & SB-12-02 & 583 & & & & & \\
\hline & SB-12-03A & & $595-625$ & $5.6-7.7$ & $590 \pm 50$ & & \\
\hline & SB-12-04 & 545 & & & & & \\
\hline \multirow[t]{3}{*}{$\begin{array}{l}\text { Moine thrust } \\
\text { sheet }\end{array}$} & $\begin{array}{l}\text { MT/SB- } \\
12-05\end{array}$ & 538 & & & & & \\
\hline & MT-12-02 & 535 & & & & & \\
\hline & MT-12-03 & 528 & & & & & \\
\hline \multicolumn{8}{|c|}{ Creich Peninsula } \\
\hline \multirow[t]{2}{*}{$\begin{array}{l}\text { Sgurr Beag } \\
\text { thrust sheet }\end{array}$} & SB-12-13 & 680 & & & & & \\
\hline & SB-12-14 & & $600-615$ & $5.6-6.1$ & $660 \pm 50$ & 610 & $5.1 \pm 1.5$ \\
\hline \multirow[t]{2}{*}{$\begin{array}{l}\text { Moine thrust } \\
\text { sheet }\end{array}$} & MT-16-03 & $470-500$ & & & & & \\
\hline & MT-12-22 & & & & & & \\
\hline
\end{tabular}

